\title{
ORCHID DISTRIBUTION AND BIOCLIMATIC NICHES AS A STRATEGY TO CLIMATE CHANGE IN AREAS OF TROPICAL DRY FOREST IN COLOMBIA
}

\author{
Guillermo A. Reina-Rodríguez ${ }^{1,3}$, Jorge E. Rubiano Mejía², Fabio A. Castro Llanos² \\ \& IGNASI SORIANO ${ }^{1}$
}

${ }^{1}$ Department of Evolutionary Biology, Ecology and Environmental Sciences., University of Barcelona, Section of Botany and Mycology. Av. Diagonal 643. E-08028 Barcelona, Spain. C.P. 08028

${ }^{2}$ Department of Geography, Valle University, Cali, Colombia. Av. Pasoancho 100-00, Cali, Colombia.

${ }^{3}$ Author for correspondence: guireina@hotmail.com

ABstract. Climate change projections in Colombia predict an average increase in temperature of $2.6^{\circ} \mathrm{C}$ and in precipitation of $20 \%$ by the end of the century. These changes would directly affect the tropical dry forest (TDF) and its biodiversity. Epiphytic orchids, more exposed to the atmosphere than the terrestrial biota, remain dependent on climatic variables, making them particularly susceptible to climate change. We studied the spatial and temporal changes of a focal group of 12 orchid species typical of the TDF in Colombia, and the future conservation areas to this ecosystem. The algorithm used by MaxEnt was employed for modelling. A total of 439 records: direct observations (276); herbaria collections (159) and bibliographical sources (4) collected since September 2009 to April 2015 were considered for use in training the model. The actual potential niche was compared to the SRES 8.5 climate change emissions scenario for two periods: 2020-2049 (2030) and 2040-2069 (2050). The results indicate an altitudinal displacement compared to the present, conditioned by variables such as temperature, accessibility and precipitation. Mid-mountain areas (1300-1700 m) increased their idoneity in future potential niche models (2030 and 2050) to the detriment of the lowlands $(0-1000 \mathrm{~m})$. Other variables analysed, such as distance thresholds of pollinators (Euglossini), availability of phorophytes, and distances to TDF cover and protected areas, all suggest an improving connectivity between the lowland and mid-mountain areas. Consequently, bioclimatic niches (BN) are proposed as a new landscape management unit. Throughout the country, 69 of these BN were located as an adaptation-conservation strategy against climate change in the TDF in Colombia.

RESUMEN. Las proyecciones del cambio climático en Colombia, indican en promedio un incremento en $2.6^{\circ} \mathrm{C}$ de temperatura y $20 \%$ de la precipitación para el fin del siglo. Estos cambios afectarán directamente al bosque seco tropical (Bs-T) y su biodiversidad. Las orquídeas epífitas, más expuestas a la atmósfera que la biota terrestre mantienen dependencia de variables ligadas al clima. Esta condición las hace particularmente susceptibles al cambio climático. Nosotros estudiamos los cambios espacio-temporales de un grupo focal de 12 especies de orquídeas típicas del Bs-T en Colombia y las futuras áreas de conservación de este ecosistema. El algoritmo usado por MaxEnt fue empleado para el modelamiento. Un total de 439 registros: observaciones directas (276); registros de herbario (159) y fuentes bibliográficas (4), colectadas desde septiembre de 2009 hasta abril 2015 fueron consideradas para entrenar el modelo. El nicho potencial actual fue comparado con el escenario de emisiones de cambio climático SRES 8.5 para dos periodos: 2020-2049 (2030) y 2040-2069 (2050). Los resultados indican un desplazamiento altitudinal respecto al presente, condicionado por variables como: temperatura, accesibilidad, y precipitación. Las áreas de montaña media (1300-1700 m) incrementarán su idoneidad en los modelos de nicho potencial futuro (2030 y 2050) en detrimento de las tierras bajas (0-1000 $\mathrm{m})$. Otras variables analizadas como umbrales de distancia en polinizadores (Euglossini), disponibilidad de forófitos, distancias a coberturas de Bs-T y áreas protegidas, sugieren mejorar la conectividad entre tierras bajas y áreas de montaña media. En consecuencia, los nichos bioclimáticos $(\mathrm{BN})$ son propuestos como nueva unidad 
de manejo del paisaje. En todo el país, 69 de ellos fueron localizados como estrategia de adaptación-conservación frente al cambio climático en áreas de Bs-T en Colombia.

KeY worDs: bioclimatic niches, climate change, Euglossini, orchids

Palabras Clave: Bosque seco tropical, cambio climático, Euglossini, nichos bioclimáticos, orquídeas

Introduction. It is a challenging problem to understand and predict how organisms and plant communities respond to climate change and what is that response. A first research line focus on Bioclimatic Envelope Models (BEMs) still lack an ecological sense. Some authors use BEM to project the rank / abundance of current distribution of the species(s) including climate change (Bellard et al. 2012, Pearson \& Dawson 2003, Thomas et al. 2004, Thuiller et al. 2004, Thuiller et al. 2008) and a second research line focus on controlled experiments (Bilton et al. 2016, Lloret et al. 2009, Peñuelas et al. 2007) but the models do not yet have ecologically meaningful processes representing orchids life cycle, e.g. dispersal, pollinating insects, phorophytes, mycorrhizae. We had included some of these as a posteriori analysis.

In this paper we define a "bioclimatic niches" from the evaluation of biotic and abiotic variables complementary to the model per se and we provided an ecological, dynamic and pragmatic sense to face the climatic change from the modelling of 12 orchids species in five areas of Tropical Dry Forest (TDF) in Colombia. The bioclimatic niches are areas where government and environmental agencies must focus conservation efforts.

Climate change and land-cover changes by anthropogenic activities are usually the main responsible factors altering the structure and function of ecosystems today (IPCC 2013). The climate change is direct threat of extinction of $4 \%$ of the vegetal species whereas the use of the land for livestock and crop farming is of $31 \%$, the selective logging is $21.3 \%$ and the housing and commercial/industrial areas on the $12.3 \%$ (RBG Kew 2016). These stressors have caused devastating effects on the ecosystem and wiped out important chorological evidence for the management, reintroduction and conservation of orchids.

The lack of spatiotemporal scientific evidence from specific areas in basins and municipalities, where organisms will move into ecosystems, delays national and local conservation strategies facing the threat of climate change. Displacements of up to 500 meters in the plant zone are predicted in Colombia, affecting 23\% of the country (GutiérrezRey 2002). In addition, the national deforestation rate is approximately 200,000 ha/year, including of TDF, of which only $3.7 \%$ remains of what existed 150 years ago. These changes will significantly affect the five main TDF areas of the country, as well as the biodiversity they contain. With the aim of designing conservation strategies to address environmental change, the objective of this study consisted of identifying potential changes in the geographic distribution of a focal group of 12 orchid species typical of the Columbian TDF (Fig. 1).

\section{Tropical Dry Forest (TDF)}

This biome of lowlands and deciduous trees has three months or more of drought annually, with ecological processes marked by their seasonality (Pennington et al. 2006). Our data show no more than 32 orchids species $/ \mathrm{km}^{2}$ in Colombian TDF. During the Pleistocene, the TDF would have covered the interAndean valleys from northern to southern Colombia, providing refuge for flora and fauna (HernándezCamacho \& Sánchez 1992, Van der Hammen et al. 1973). Palynological evidence of areas of TDF in the Patía Valley, Cauca River Valley and savannah areas in the Eastern Plains (not included in this study) reveals the existence of these Pleistocene refuges in the last ten thousand years (Berrío et al. 2002a, 2002b, GonzálezCarranza et al. 2008, Marchant et al. 2006, Vélez et al. 2005).

At present, according to Etter et al. (2008), 8.9 million hectares in Colombia may potentially contain TDF areas that are restricted to the Caribbean region, the Santander region, south of the Magdalena Valley, the Cauca River Valley, and the Patía Valley. However, deforestation processes and the land use transformation for cattle ranching and agriculture have caused devastating effects on the ecosystem. Currently, the extent of the remnant TDF is 720,000 ha, and moreover it is poorly and insufficiently represented in the National System of Protected Areas (NSPA, 

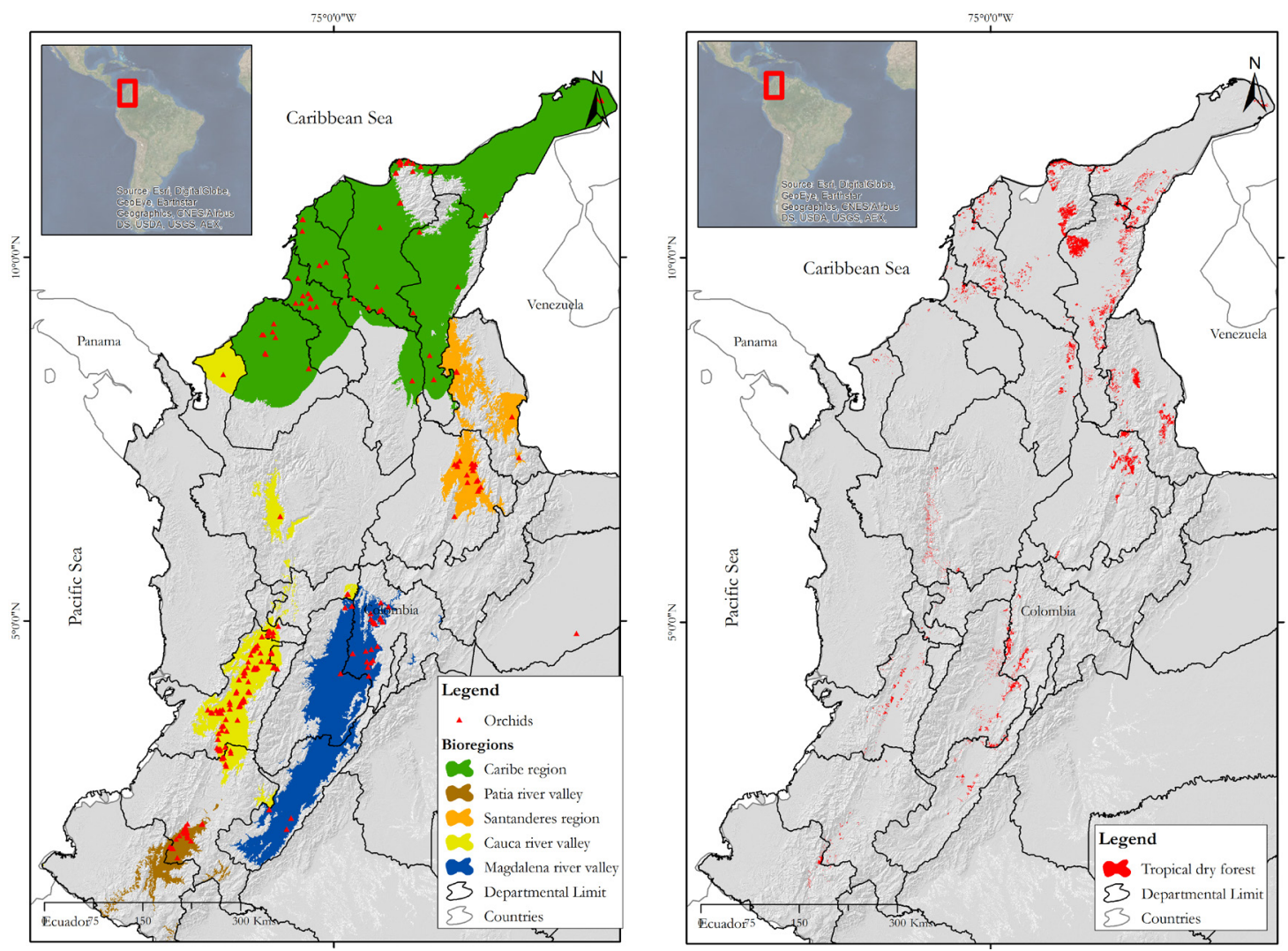

FIgURE 1. Left: Five main areas of potential TDF distribution in Colombia. Magdalena River Valley, Cauca River Valley, Caribbean region, Patía River Valley, Santander region. The red triangles indicate georeferenced records of TDF orchids in Colombia from field collections, herbarium sheets and bibliographic sources. Right: Actual distribution of TDF in Colombia. Source: Ariza et al. 2014.

in Spanish SINAP), because it accounts for only 5\% (Pizano \& García 2014).

By the 2071-2100, Colombian areas of TDF) are expected to have an increase in temperature of $2.4-2.8^{\circ} \mathrm{C}$ and will receive between 10 and $20 \%$ less rain (IDEAM et al. 2015). Climate change can also affect biota of the TDF through erratic or extreme rains, changes in evaporation, acceleration of erosive processes, modification of the microclimate and alteration of the composition of forest-grassland flora, as well as through an increase of the frequency of fires in the affected areas (Bates et al. 2008).

\section{Orchids of the Tropical Dry Forest}

Colombia with 4270 species of Orchidaceae reported, has the highest diversity of these plants in the world (Betancur et al. 2015). Their distribution, however, was defined by political-administrative areas, but not to bioregions of TDF associated with this taxonomic group, which remains a pending task. Plant inventories of the TDF reported only 81 species and 48 genera of orchids in Colombia (Pizano \& García 2014), which is quite similar in number and composition to the 70 species and 41 genera reported for the TDF of the Cauca River Valley (Reina-Rodríguez et al. 2010). This fact can be attributed to scarce efforts and the difficulties of sampling of the epiphytic biotype (mostly between 10 and 40 meters above the ground). We estimated 350 orchid species present in these five areas of TDF in Colombia. However we believe that this number can increase because there are still many unexplored areas.

The marked seasonality of the TDF is manifested in the morphological and anatomical adaptations of these plants to conditions of prolonged drought (Oliveira \& Sajo 2001) such as roots with velamen, 
idioblasts, trichomes and a thickened epidermis (Torres et al. 2007), all of which prevent water loss. Orchids and other epiphytes share light, temperature, moisture and nutrients in the forest canopy. The health of these plants is important to life cycles in the canopy, as well as to the ecosystem, not only for their contribution to trophic chains and microhabitats for invertebrates and amphibians but also because they serve as sinks of water (Richardson et al. 2000, Benzing 1998).

Orchids can respond to climate change challenges by shifting their climatic niche along three nonexclusive axes: time (e.g., phenology), space (e.g., range) and self (e.g., physiology) (Bellard et al 2012). The increase in temperature that will be induced by climate change will catalyse the migration of plants to higher latitudes and altitudes in search of suitable habitat (Chen et al. 2011). These natural migrations will maintain equilibrium with the climate and thus avoid potential extinctions (Feeley et al. 2010, Still et al. 1999). Such changes, however, modify the vegetation zone because migrations are closely linked to temperature increases (Primack \& Corlett 2005). We identifying 69 high priority areas ("bioclimatic niches") in Colombia where conservation efforts by land management agencies should be focused.

\section{Materials and methods}

Study area - . The TDF in Colombia includes localized areas between $12^{\circ} 24^{\prime} 33^{\prime \prime}$ and $1^{\circ} 39^{\prime} 35.31^{\prime \prime}$ latitude $\mathrm{N}$ and $77^{\circ} 21^{\prime} 31^{\prime \prime}$ and $70^{\circ} 27^{\prime} 43^{\prime \prime}$ longitude $\mathrm{W}$, with an average annual temperature greater than $17^{\circ} \mathrm{C}$. It corresponds to the lowlands and mountains with altitudes below $1500 \mathrm{~m}$; the precipitation does not exceed $2000 \mathrm{~mm}$, the rains are distinctly seasonal, and drought occurs for 3 months or longer (Mooney et al. 1995, Sánchez-Azofeifa et al. 2005). A population of 30.6 million people is settled in these areas (DANE 2015), which is equivalent to $63 \%$ of the Colombian population. The potential TDF cover in Colombia is 8.9 million ha, of which only $3.8 \%$ is conserved in its natural condition (Pizano \& García 2014). Considering the possibility that climate change may alter the delimitation of the TDF, for this study, the territory was expanded to include areas with a total annual precipitation between 0 and $2100 \mathrm{~mm}$ and located at a maximum elevation of $1800 \mathrm{~m}$ (Fig. 1). TDF areas of the Eastern Plains (Casanare and Arauca) and insular Caribbean (San Andrés and Providencia) were not considered for this study due primarily to the presence of soils with laterite shields, which limit the potential vegetation (Pizano \& García 2014) and secondly to the absence of primary information.

Collection of primary and secondary information —. During the 2009-2015 period, 1200 hours were spent gathering primary information, with 60 persons being directly or indirectly involved during 57 field trips. The areas explored included the TDF of the Cauca River Valley, the dry enclave of the Dagua River, the Patía River Valley, south of the Magdalena Valley, the Caribbean region and the department of Santander. More than 200 linear $\mathrm{km}$ were covered ad libitum with two or more expert observers, who used $8 \times 40$ binoculars to locate canopy orchids. The final expeditions were defined using the map of TDF in Colombia (Ariza et al. 2014) (Fig. 1).

In addition, geographic information was gathered from specialized scientific literature and botanical specimens deposited in the following 15 national and international herbaria: CUVC: Valley University, Cali; VALLE: National University, Palmira; TULV: Botanical Garden Juan María Céspedes Herbaria, Tuluá; CAUP: Cauca University, Popayán; CDMB: Eloy Valenzuela Botanical Garden, Floridablanca; COL: National Colombian Herbaria, Bogotá; FMB: Alexander von Humboldt Institute, Villa de Leyva; HUC: Córdoba University, Montería; Guillermo Piñeres Botanical Garden, Cartagena de Indias; UIS: Industrial University of Santander, Bucaramanga; UTMC: Magdalena University, Santa Marta; HPUJ: Pontifical Xavieriana University, Bogotá; Quindío University, Armenia; BC: Botanical Institute of Barcelona, Barcelona; and AMO: Mexican Association of Orchidology, México D.F. The data collected were sufficient for niche modeling and also improved the knowledge of the distribution range of these plants in areas of TDF in Colombia.

Orchid selection -. In total, 12 "core" species typical of TDF orchids in Colombia were selected; their classification and distribution ranges are shown in Appendix 1. Information from collections and/ or field observations, as well as from the herbarium 
sheets, was compiled in a Darwin core format database (Wieczorek et al. 2012) available at http://rs.tdwg. org/dwc. This database consists of the 439 records were used to generate the model. The database also contains 314 aditional records of TDF orchid species different from the "core" species, as well as additional information, yielding a total of 753 records. Parts of these records are currently published as biological data sets in the form of three data sets; orchid associated flora-phorophytes, orchids observed in the field and orchids identified in herbaria which can be consulted in: http://i2d.humboldt.org.co/ceiba/ resource.do?r=rrbb_bst_orquideas_2015; http:// i2d.humboldt.org.co/ceiba/resource.do? r=rrbb_bst orquideas_observaciones_2015 http://i2d.humboldt. org.co/ceiba/resource.do?r=rbb_bst_orquideas identificaciones_2015

The selection criteria for these species were as follows: a) more than 18 records per species are required for greater reliability with MaxEnt; $b$ ) records were within the five areas of potential TDF delimited for Colombia; c) georeferenced records that occupy the same $1 \times 1 \mathrm{~km}$ pixel were excluded to prevent over-estimation (over-fitting) in the model and to permit good discrimination between presences and pseudo-absences (Isaac et al. 2009, Van der Wal et al. 2009); d) species were geographically representative and complementary in TDF areas in Colombia such that they were present in most of the five areas studied. These characteristics are associated with the TDF species. Among the selected species, Trizeuxis falcata Lindl. has flattened and streamlined shapes to reduce the effects of the wind; Cyrtopodium paniculatum (Ruiz \& Pav.) Garay and Catasetum tabulare Lindl. have large pseudobulbs and lose their leaves when the dry season is prolonged; Epidendrum rigidum Jacq., Trichocentrum carthagenense (Jacq.) M.W. Chase \& N.H. Williams and Polystachya foliosa (Hook.) Rchb. have leathery leaves with thick cuticles to prevent water loss; Vanilla calyculata Schltr. has swollen stems to store a greater volume of water; and Scaphyglottis prolifera (Sw.) Cogn. has multiple elongated pseudobulbs as a strategy for water storage.

Modelling algorithm - . For modelling, the maximum entropy algorithm was used in the application MaxEnt (Elith et al. 2006, 2011, Phillips et al. 2006, Phillips \&
Dudík 2008). This algorithm uses maximum entropy and Bayesian methods to estimate the probability distribution of each species based on their presence or absence and pseudo-absences, which are defined as areas where presence or absence of the species is uncertain. The algorithm used by MaxEnt is one of the most robust models of species distribution (MSD) in terms of successfully estimating the area from only a few records of presence (Hernández et al. 2006), as occurs with most tropical epiphytes. MaxEnt has been widely tested for species idoneity in both present and future conditions (Merow et al. 2013, Phillips 2008, Reina-Rodríguez et al. 2016) and has been used with actual species from more than ten locations (RamírezVillegas et al. 2014, Wiz et al. 2008). In this study, to avoid over-fitting (Barbet-Massin et al. 2012), 2120 pseudo-absences were included, with ten for each presence obtained from our database (herbaria data and fieldwork) in TDF-delimited areas.

Given that a species can migrate and occupy new locations under future climatic conditions, we consider that by limiting the study area up to $1800 \mathrm{~m}$ and precipitation to $2100 \mathrm{~mm}$ /year, the thresholds of commission (too far from the niche of the taxon) and omission (lack of observations) are assumed implicit in the areas and periods proposed in this study.

\section{Selection and preparation of modelling variables}

For modelling, the potential niche or habitat idoneity is understood as the $n$-dimensional area where the species encounters the conditions that allow its survival and reproduction (Wiens et al. 2009). A total, 19 variables correspond to bioclimatic parameters associated with the baseline annual temperature and precipitation characteristics (1950-2000) (Hijmans et al. 2005) were selected. The other three variables were altitude, taken from the Digital Elevation Model (DEM) at $1 \mathrm{~km}$ (Jarvis et al. 2004); forest cover (Hansen et al. 2013); and accessibility, measured as time in minutes to get to a town of over 50,000 inhabitants, which was taken from the Joint Research Centre, available at http://ec.europa. $\mathrm{eu} / \mathrm{jrc} /$. Additional factors considered were the availability of free-access climatic data, a spatial resolution of $1 \mathrm{~km}$ and spatial cover. Large number of predictors in MaxEnt may cause excess in the 
TABLE 1. Variables selected for the modelling of present and future scenarios. Bold indicates the seven variables selected by means of the Variance Inflation Factor (VIF) $<10$. The $\left(^{*}\right)$ indicates variables excluded by low percentage contribution in the first iteration according to the model.

\begin{tabular}{|c|c|c|c|c|}
\hline Variable & Brief Description & Unit of Measure & Source & VIF \\
\hline Bio $2^{*}$ & Average daytime temperature range & Degrees centigrade & \multirow{8}{*}{$\begin{array}{l}\text { Hijmans } \\
2005\end{array}$} & 1.6 \\
\hline Bio 3 & Isothermality. Index of temperature variability & $\begin{array}{l}\text { Reason for average diurnal range with } \\
\text { respect to annual range }\end{array}$ & & 3.5 \\
\hline Bio 4 & Temperature seasonality & Standard deviation * 100 & & 2.2 \\
\hline Bio 8 & Average temperature of the wettest trimester & Degrees centigrade & & 2.2 \\
\hline Bio 13 & Precipitation of the wettest month & Millimetres & & 2.3 \\
\hline Bio 14 & Precipitation of the driest month & Millimetres & & 3.7 \\
\hline Bio $18^{*}$ & Precipitation of the warmest trimester & Millimetres & & 1.5 \\
\hline Bio $19^{*}$ & Precipitation of the coldest trimester & Millimetres & & 0.7 \\
\hline Tree cover & Forest cover & Percentage of area & $\begin{array}{c}\text { Hansen } \\
2013\end{array}$ & 2.1 \\
\hline Acc & $\begin{array}{l}\text { Accessibility to population centres of more than } 50,000 \\
\text { inhabitants }\end{array}$ & Time in minutes & $\begin{array}{c}\text { Joint } \\
\text { Research } \\
\text { Centre }\end{array}$ & 3.5 \\
\hline
\end{tabular}

fit (over-fitting), thereby skewing the responses (Warren \& Seifert 2011). To reduce the number of variables, the Variance Inflation Factor statistical technique (VIF) was applied, which consists of a multiple regression analysis to identify the least colinear variables among them, or, in other words, to determine which variables do not depend on others. The value VIF $<10$ (Montgomery et al. 2006) was used as a maximum threshold to reduce the number of variables for discarding in subsequent modelling routines (Austin \& Van Niel 2011, Montgomery et al. 2006). This preliminary analysis reduced the number of variables to be used from 22 to 10 . The Table 1 shows these variables used for performing the final routines for the climate of the present, near future (2030) and distant future (2050).

For modelling potential niches under climate change conditions, altitude and accessibility variables remained fixed. Forest cover was adjusted to an annual deforestation rate of $2 \%$ for 2030 and $4 \%$ for 2050 , which was based on the current value reported in Colombia of 200,000 hectares per year (Reymondin et al. 2010). Climatic variables were taken from the projections conducted by the IPCC (2013), and the RCP 8.5 emission scenario of the fifth assessment report (AR5) was chosen for this study, specifically the projections for the 2020-2049 and 2040-2069 periods, referred to in this study as 2030 and 2050, respectively. This scenario was chosen because it represents the most likely path of events related to the production of greenhouse gases (GHG) emitted by the energy, industry, agriculture and forestry sectors, and it also combines interdisciplinary models that operate at different spatial resolutions and are interrelated and integrated into an overall evaluation framework (Riahi et al. 2007). The RCP 8.5 scenario predicts an increase of $2.7^{\circ} \mathrm{C}$ in average temperature and a change of $20 \%$ annual precipitation by the year 2069 and resembles the projections for Colombia conducted by IDEAM (2015) for the period 2041-2070.

\section{Evaluation of model performance, behaviour and results}

Three statistical methods were used to evaluate the quality and performance of the models obtained. Testing values for the area under the curve (AUC) indicate the ability of the model to discriminate presences from absences. AUC values oscillate between 0 , which indicates randomness, 
to 1.0 , which indicates greater discrimination (Engler et al. 2004); values of $\mathrm{AUC}<0.7$ indicate poor models; values $0.7>x<0.9$ indicate moderately useful models; and $x>0.9$ indicate excellent models (Pearce \& Ferrier 2000). The Cohen's Kappa index was also calculated, which assesses the effect of randomness in associating observed objects to a specific classification category (Viera \& Garret 2005). Concordance was thus identified from the results of the 25 iterations performed through cross-validation (Hijmans et al. 2012), using the sensitivity threshold Maximum test sensitivity logistic threshold as a reference (Liu et al. 2013). The model fit from the Kappa value was estimated by following the ranges proposed by Monserud \& Leemans (1992) (See Appendix 2).

The spatial distribution patterns of orchids obtained for present and future conditions were quantified and compared to each other by identifying, for the entire study area, the potential gain or loss of the areas in which these species occur. To explore conservation strategies, this quantification also considered regional conglomerates of TDF, administrative units (Departments) and the Protected Areas listed in the Only National Register of Protected Areas (Registro Único Nacional de Áreas Protegidas - RUNAP) and in the Private Reserves of Civil Society (Reservas Privadas de la Sociedad Civil -NRCS), all of which have influence on the TDF areas throughout Colombia.

Idoneity indices - - Indices have been frequently used to estimate spatiotemporal changes (Armenteras et al. 2006, Mcgarigal \& Marks 1995, Reina-Rodríguez \& Soriano 2008, Rudas et al. 2002). In this study, three indices of idoneity were calculated for the 2030 and 2050 periods to assess the magnitude of future changes that can promote understanding of the spatiotemporal dynamics.

\section{Index of tropical dry forest orchids IoBsT}

This index represents the national magnitude of future idoneity, IoBsT_30 and IoBsT_50, compared to the present total idoneity.

$$
I o B s T=\frac{\text { Suitability }_{t 30, t 50}}{\text { Total Suitability }_{t \text { Present }}} * 100
$$

Bioregional index of Tropical Dry Forest orchids IoBioreg

This index expresses the bioregional magnitude of future change, IoBioreg_30 and IoBioreg_50, with respect to the value of present idoneity in the bioregion in question.

$$
\text { IoBioreg }=\frac{\text { Suitability }_{\text {t30,t50 }}}{\text { Suitability Bioregion }_{\text {tPresent }}} * 10
$$

Severity index of tropical dry forest orchids IoShp

The severity index expresses the strength or intensity of change. It is the ratio of the present idoneity with respect to the value of future idoneity, IoShp_30 and IoShp_50, in the bioregion in question.

$$
I o S h p=\frac{\text { Suitability Bioregion }_{t \text { Present }}}{\text { Suitability }_{t 30, t 50}}
$$

Proposal of bioclimatic niches - Factors such as the persistence of certain species under climate change, migration speed, ecotones, immigration potential, and spatiotemporal plant-pollinator relations are excluded from predictive studies (Ibáñez 2006). Given that the current model generation does not consider factors that may increase biological realism and therefore approximation in future predictions (Urban 2015), $a$ posteriori evaluations were proposed for the models obtained to identify where refuge areas for these plants would be in the Colombian TDF. A previous selection criteria filtered areas by river basins, with $p>0.61$ for the model obtained for the 2050 period. Subsequently, a Geographic Information System (GIS) and expert judgment were used to evaluate biotic and abiotic conditions complementary to the model. The biotic conditions were a) composition of the flora, b) presence of pollinators and c) presence of mycorrhizae. The abiotic conditions were a) altitudinal gradient, b) relief and c) distance to Protected Areas (PA and NRCS) and TDF fragments.

It was verified in $25 \%$ of the points, the presence of flora associated with at least three of the phorophytes reported in Table 2, were present within a radius of $23 \mathrm{~km}$. From the biotic approach, wasps and bees are responsible for the transport and pollination of $60 \%$ of Orchidaceae (Ackerman 1983, Camargo et al. 2006, Whitten et al. 1993, Williams 1982). Large pollinators, 
TABLE 2. Biotic and abiotic conditions evaluated for locating climatic niches proposed as a refuge for orchids of the Tropical

Dry Forest (TDF) in Colombia.

\begin{tabular}{|c|c|}
\hline Biotic conditios & Requirements \\
\hline a) Composition of flora & $\begin{array}{l}\text { Presence of at least three of these phorophytes: Pseudobombax septenatum, Anacardium excelsum, Luehea } \\
\text { seemannii Planch. \& Triana, Guarea guidonia, Guazuma ulmifolia, Brosimum alicastrum, Calliandra pittieri, C. } \\
\text { magdalenae, Samanea saman, Tetrorchidium rubrivenium Poepp., Guapira cf. costaricana (Standl.) Woodson, } \\
\text { Ficus insipida, Erythroxylum ulei O.E. Schulz, Maclura tinctoria (L.) D. Don ex Steud., Crescentia cujete, } \\
\text { Machaerium capote, Caesalpinia punctata Willd., Psidium guajava, Erythrina poeppigiana, Poulsenia armata } \\
\text { (Miq.) Standl., Astronium graveolens Jacq., Sterculia apetala (Jacq.) H.Karst and Daphnopsis americana (Mill.) } \\
\text { J.R. Johnst. }\end{array}$ \\
\hline b) Presence of pollinators & $\begin{array}{l}\text { Presence of Euglossini bees (Hymenoptera: Apidae) such as Eulaema, Euglossa, Eufriesea and Exaerete. } \\
\text { Thresholds less than } 23 \text { linear km are reached by these bees (Dressler 1982, Janzen 1971). Therefore, orchids } \\
\text { and other TDF plants are also reached. }\end{array}$ \\
\hline c) Mycorrhizae & $\begin{array}{l}\text { Molecular studies of orchid-fungal associations, which indicate geographic range of mycorrhizal fungi are much } \\
\text { larger than the range of the orchids themselves (Phillips et al 2014). Therefore we consider that forests of more } \\
\text { than } 10 \text { ha and physiognomically well structured, harbor the mycorrhiza necessary for the development of } \\
\text { seedlings. }\end{array}$ \\
\hline Abiotic conditions & Requirements \\
\hline a) Altitudinal gradient & $\begin{array}{l}\text { Availability of } 175 \text { to } 350 \text { metres of altitudinal gradient in the next } 25 \text { to } 50 \text { years to compensate for an increase } \\
\text { in temperature and possible extinctions (Feeley 2011, Lutz et al. 2013) }\end{array}$ \\
\hline b) Relief & $\begin{array}{l}\text { Moderate to very steep slopes. Presence of deep channels (canyons) with vegetated bottoms and slopes. } \\
\text { Presence of rocky formations with cavities. Establishment of agriculture or population centres is not possible. }\end{array}$ \\
\hline $\begin{array}{l}\text { c) Distance to protected } \\
\text { areas and/or fragments } \\
\text { of TDF forest. Size } \\
\text { of fragmented forest } \\
\text { patches. }\end{array}$ & $\begin{array}{l}\text { According to the TDF map (IAvH 2014) and the only national record of protected areas (RUNAP). Dense forest } \\
\text { cover or sub-xerophytic shrubland greater than } 10 \text { ha (Harris 1984). }\end{array}$ \\
\hline
\end{tabular}

such as Euglossini bees (Hymenoptera: Apidae), have foraging routes up to $23 \mathrm{~km}$ long (Janzen 1971). Orchids pollinated by genera Eulaema Lepeletier, Eufriesea Cockerell, Exaerete Hoffmannsegg and Euglossa Latreille, can thermoregulate allowing them to fly under conditions of low humidity and high temperature, which are typical of open spaces (Janzen 1974, May \& Casey 1983, Roubik 1993). They are present from Mexico to Argentina in several types of dry and semideciduous ecosystems (Rebêlo \& Garófalo 1997), humid forests (Roubik \& Ackerman 1987, Sandino 2004) and Amazonian forests (Becker et al. 1991). These pollinators ensure genetic variability through cross-pollination increasing the chance of surviving environmental changes and also migrate along altitudinal gradients from the lowlands to highlands in response to temperature increases and resource availability (Uehara-Prado \& Garófalo 2006). This evolutionary adaptation gives this group of insects a key role under climate change conditions because in a short-term climate change effects are not expected for this group of organisms (Roberts 2003).
Emerging evidence from other molecular studies of orchid-fungal associations, indicate that geographic range of mycorrhizal fungi appears to be typically much larger than the range of the orchids themselves. (Phillips et al. 2014). For the analysis, we consider that forests of more than 10 ha and physiognomically well structured, harbour the orchid mycorrhiza necessary for the development of seedlings.

\section{Results}

Current knowledge of the orchids of TDF in Colombia -. Preliminary data of Orchidaceae in the TDF of Colombia indicate that 53 species exist in the Caribbean bioregion at altitudes $<1000 \mathrm{~m}$ (Betancur et al. 2015); 127 species in the Santander bioregion (Martínez et al. 2015); 73 species in the Magdalena Valley (Bernal et al. 2015), with data mainly from the north (Antioquia) with gaps towards the south (Huila, Tolima); and 70 species in the Cauca River Valley (Reina-Rodríguez et al. 2010). According to our data on the Patía Valley, 
TABLE 3. Representativeness of the selected species in the Colombian Tropical Dry Forest (TDF) . In each cell, the number of records of the species from the database generated for all Colombia is shown. Numbers in bold are higher than the average. $\mathrm{PV}=$ Patia river valley, $\mathrm{CV}=$ Cauca river valley, $\mathrm{MV}=$ Magdalena river valley, $\mathrm{SR}=$ Santander region, $\mathrm{CR}=\mathrm{Caribbean}$ region .

\begin{tabular}{|c|c|c|c|c|c|c|}
\hline \multirow[b]{2}{*}{ Species } & \multicolumn{6}{|c|}{ Regions of tropical dry forest (Bs-T) in Colombia } \\
\hline & PV & CV & MV & SR & CR & $\begin{array}{c}\text { Total species } \\
\text { records }\end{array}$ \\
\hline Brassavola nodosa (L.) Lindl & 0 & 0 & 3 & 4 & 20 & 27 \\
\hline Catasetum tabulare Lindl & 14 & 11 & 2 & 0 & 1 & 28 \\
\hline Cyrtopodium paniculatum (Ruiz \& Pav.) Garay & 7 & 13 & 2 & 5 & 28 & 55 \\
\hline Dimerandra emarginata (G. Mey.) Hoehne & 1 & 25 & 2 & 9 & 13 & 50 \\
\hline Epidendrum rigidum Jacq. & 3 & 19 & 6 & 2 & 2 & 32 \\
\hline Jacquiniella globosa (Jacq.) Schltr & 0 & 23 & 4 & 2 & 2 & 31 \\
\hline Oeceoclades maculata (Lindl.) Lindl & 7 & 6 & 5 & 11 & 19 & 48 \\
\hline Polystachya foliosa (Hook.) Rchb.f. & 0 & 14 & 6 & 2 & 4 & 26 \\
\hline Scaphyglottis prolifera (Sw.) Cogn. & 0 & 21 & 5 & 6 & 2 & 34 \\
\hline Trichocentrum carthagenense (Jacq.) M.W. Chase \& N.H. Williams & 1 & 19 & 3 & 5 & 12 & 40 \\
\hline Trizeuxis falcata Lindl. & 7 & 22 & 8 & 12 & 1 & 50 \\
\hline Vanilla calyculata Schltr. & 4 & 12 & 1 & 0 & 1 & 18 \\
\hline Total regional records & 45 & 185 & 48 & 56 & 105 & 439 \\
\hline
\end{tabular}

orchids species would not exceed 30 species. This group would be the most vulnerable to the effects of Climate Change due to the total absence of conservation areas.

The database compiled in the Darwin core contains 439 records of orchids from the Colombian TDF, of which, 276 correspond to herbarium collections, 159 to direct observations and four to bibliographic sources. Data indicate the presence of these taxa in five TDF areas in Colombian territory. The TDF map for Colombia, which was elaborated by the Alexander von Humboldt Institute (Ariza et al. 2014) and discussed by Pizano \& García (2014), places the TDF ecosystem in Colombia in 22 departments and 314 municipalities. Concerning our 12 focal orchids support the presence of these plants in 19 departments and 118 municipalities. In other words, slightly more than half of the municipalities (196) lack records for these species, suggesting important geographical information gaps. By bioregion, the Cauca River Valley and the Caribbean region have higher than average values. The Patía River Valley and Magdalena River Valley have the poorest values. The representativeness of each 'core' species of the TDF is shown in Table 3.
Evaluation of the model and influencing variables -. From the filtering of the 439 records of our database, 212 points (one record per pixel of $1 \mathrm{~km}^{2}$ ) were selected for these training tests. The AUC values for training tests of the twelve species ranged between 0.8562 and 0.8641 , with $x^{\prime}=0.8598$, whereas the test data ranged between 0.6702 and 0.9721 , with 0.8126 . AUC data for future periods yielded a value of 0.8825 , and those from the test yielded 0.7570 . Because the values have an AUC $>0.7$, the model is considered 'very good' (Pearce \& Ferrier 2000) and is consistent for species discrimination. The Kappa index demonstrates model performance and compares model prediction to random prediction (Naoki et al. 2006). In other words, it is a measure to assess the random effect and its concordance with what is observed. For our analysis, the degree of agreement is 0.85 , which is within the $0.85 \leq K<0.99$ range and qualifies it as excellent according to (Monserud \& Leemans 1992), which indicates a high degree of agreement; therefore, the data used in the modelling can be regarded as reliable.

The most important variables in the model were the seasonality of temperature Bio 4, which explained 
Table 4: Bioclimatic niches for the 2050 period and proximity to tropical dry forest (TDF) areas (Ariza et al. 2014), public protectec areas (PA) and private protected areas (NRCS) in the five bioregions of TDF in Colombia.

\begin{tabular}{|c|c|c|c|c|c|c|c|c|c|}
\hline Bioregion & $\begin{array}{c}\text { (a) } \\
\text { Number of } \\
\text { basins with } \\
\text { suitability areas } \\
p>0.61\end{array}$ & $\begin{array}{c}\text { Suitability } \\
\text { areas } p> \\
0.61 \\
\text { (ha) }\end{array}$ & \begin{tabular}{|l} 
(b) \\
No. Polygons \\
of TDF < 23 \\
km \\
(ha)
\end{tabular} & $\begin{array}{c}\text { Areas of } \\
\text { TDF }<23 \\
\text { km } \\
\text { (ha) }\end{array}$ & $\begin{array}{c}\text { (c) } \\
\text { No. PA } \\
<23 \mathrm{~km}\end{array}$ & $\begin{array}{c}\text { Area of } \\
\text { PA }<23 \\
\text { km } \\
\text { (ha) }\end{array}$ & $\begin{array}{c}\text { (d) } \\
\text { No. } \\
\text { NRCS } \\
<23 \text { km }\end{array}$ & $\begin{array}{c}\text { Areas of } \\
\text { NRCS } \\
<23 \mathrm{~km} \\
\text { (ha) }\end{array}$ & $\begin{array}{c}\text { Altitudinal } \\
\text { range: } \\
(\mathrm{a}-\mathrm{b}) ;(\mathrm{a}-\mathrm{c}) ; \\
\text { (a-d) } \\
\text { (meters) }\end{array}$ \\
\hline $\begin{array}{l}\text { Cauca } \\
\text { River } \\
\text { Valley }\end{array}$ & 13 & 115,256 & 239 & 28,111 & 25 & 62,571 & 23 & 946 & $629-1796$ \\
\hline $\begin{array}{l}\text { Caribbean } \\
\text { Region }\end{array}$ & 8 & 4756 & 91 & 76,436 & 0 & - & 2 & 446 & $0-1485$ \\
\hline $\begin{array}{l}\text { Magdalena } \\
\text { Valley }\end{array}$ & 15 & 49,061 & 157 & 63,848 & 16 & 33,320 & 4 & 13 & $237-1790$ \\
\hline $\begin{array}{l}\text { Patía } \\
\text { Valley }\end{array}$ & 1 & 9299 & 10 & 1.186 & 0 & - & 0 & - & $612-1443$ \\
\hline $\begin{array}{l}\text { Santander } \\
\text { Region }\end{array}$ & 8 & 9235 & 112 & 76,205 & 11 & 57,236 & 0 & - & $154-1798$ \\
\hline Total & 45 & 187,607 & 609 & 245,786 & 52 & 153,127 & 30 & 1405 & $0-1798$ \\
\hline
\end{tabular}

$26.9 \%$; the average temperature of the wettest trimester Bio 8, which explained 22.9\%; and isothermality Bio 3, which explained $3.5 \%$. These variables account for a total of $53 \%$ of the thermal influence and, consequently, the altitudinal influence in the model explanation. Accessibility to population centres of more than 50,000 inhabitants contributed $35.1 \%$, which suggests a negative anthropogenic influence from proximity to urban and populated areas to locations where populations of orchids are found. Precipitation of the wettest month Bio 13 explained 2.3\%, and precipitation of the driest month Bio 14 explained 3.7\%, together add up to $6 \%$ of the explanation being influenced by the contribution of water seasonality to the model, is obviously indispensable for epiphytic and terrestrial orchids in terms of their physiological requirements, with the orchids depending on water reserves held in their specialized morphological structures. Finally, the forest cover explained $2.1 \%$, which demonstrates the importance of a defined forested structure and, more specifically, the need for suitable phorophytes for the establishment of orchids.

Altitudinal migration of tropical dry forest orchids Data points obtained from the modelling totalled $\mathrm{n}=16,547$, with idoneity $p>0.61$ and a pixel size of $1 \mathrm{~km}^{2}$. The ANOVA results indicated statistically significant differences among the different combinations of the periods analysed (present-2030, present-2050 and 2030-2050) with $p<0.05$, showing drastic changes between the periods and also bioregion in the altitudes required by these plants, which are attributed to the effect of climatic change, reflecting the areas suitable for orchids in TDF for the next 50 years (see Appendix 3). The Caribbean region would be at approximately $954.3 \pm 141.1 \mathrm{SD} \mathrm{m}$ during the 2050 period, while the bioregion of the Cauca River Valley for the same period would be at 1393.6 $\pm 183.4 \mathrm{SD}$ m, identified as a suitable altitude under future climate scenarios according to the model. In the Caribbean bioregion, the availability of area will be concentrated at the Sierra Nevada of Santa Marta where net idoneity and forest cover still exists in 6 basin (see Appendix 5). At the other extreme, the suitability for orchids in the Cauca River Valley there is availability of areas and altitude gradients found below $15 \mathrm{~km}$ distance of the current populations in both the Dagua Canyon and Cauca River Valley; however, anthropogenic factors limit the coverage required for the establishment of these plants (Reina-Rodríguez et al. 2016).

On the other hand, the Patía and Santander bioregions show similarities in the 2030 period $(1121.3 \pm 174.3 \mathrm{SD} \mathrm{m}$ and $1140.9 \pm 166.7 \mathrm{SD} \mathrm{m}$, respectively) and the 2050 period (1269.7 $\pm 147.1 \mathrm{SD}$ and $1275.5 \pm 150.6 \mathrm{SD}$, respectively) in the altitudinal suitability requirements for both periods and also 


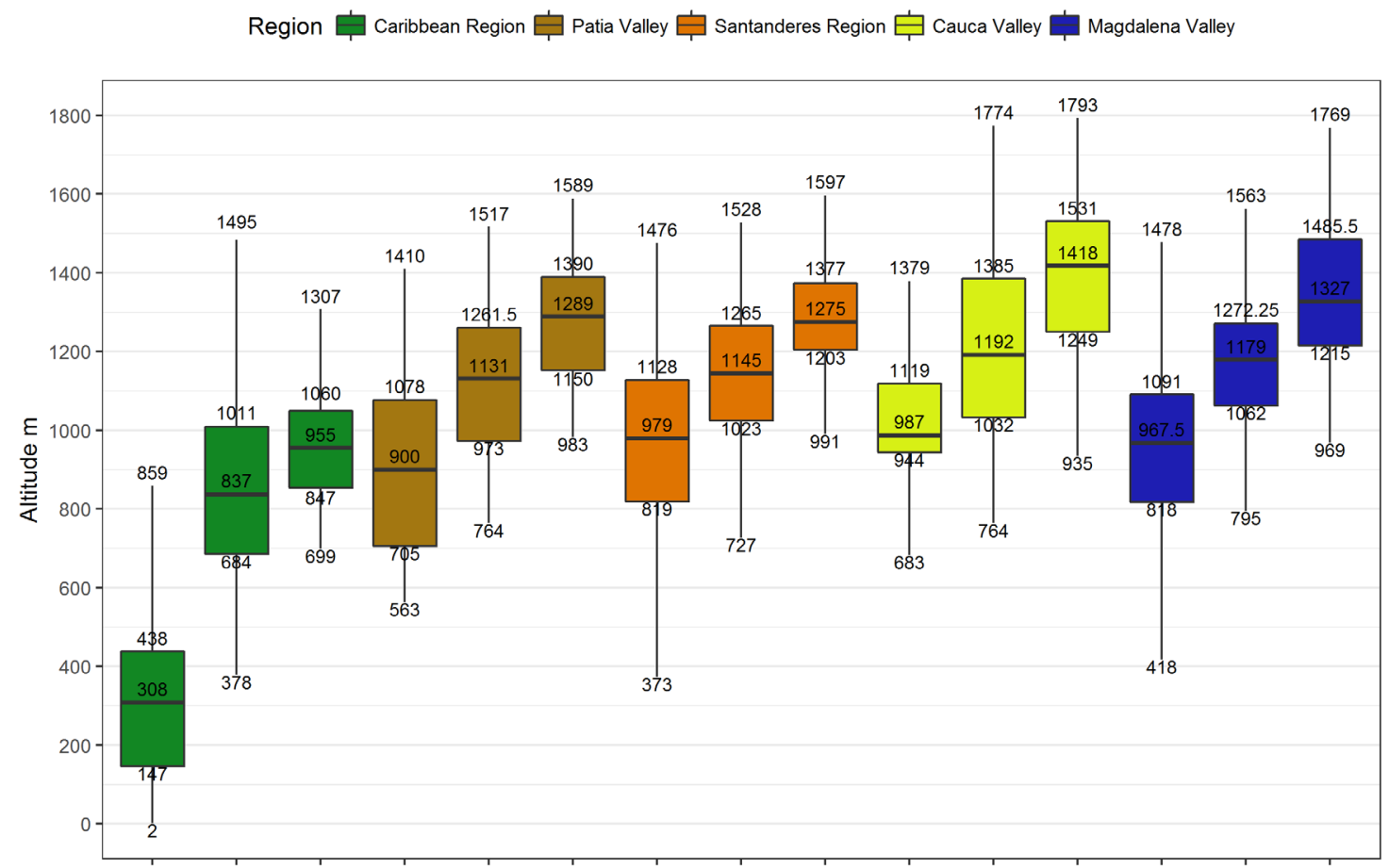

FIgURE 2. Altitudinal and temporal spectrum of suitability by bioregions for 12 species of orchids of Tropical Dry Forest (TDF) in Colombia. $1^{\text {st }}$ position of the series=Present, $2 \mathrm{nd}=2030$ and 3rd=2050. Caribbean Region: Present $(n=460)$, $2030(n=286)$ and $2050(n=60)$. Patía River Valley: Present $(n=380), 2030(n=173)$ and $2050(n=115)$. Santander Region: Present $(n=1510), 2030(n=471)$ and $2050(n=110)$. Magdalena river Valley: Present $(n=1644), 2030(n$ $=544)$ and $2050(n=585)$. Cauca river Valley: Present $(n=6599), 2030(n=2128)$ and $2050(n=1482)$.

coincide in terms of the minimum size of suitable area (9299 ha and 9235 ha areas $p>0.61$ respectively see Table 4), suggesting similar dispersal patterns and possible convergent management strategies.

In a comparison of the SRES-A2 emission scenario of climate change obtained for the Cauca Valley for the 2100 period by Reina-Rodríguez et al. (2016) with the RCP 8.5 emission scenario used in this manuscript, the altitudinal suitability in the last quartile $(25 \%$ of the data) of the SRES-A2 is between 1210 and 1470 $\mathrm{m}$ and is more similar to the second and third quartile ( $50 \%$ of the data) of the RCP 8.5 , with a suitability range of $1220-1500 \mathrm{~m}$ for the 2050 period. Some overlap was found between the suitability of areas of the Western Cordillera and north of the Cauca River Valley; however, most of the suitability for the RCP 8.5 scenario changes from the eastern slope of the Western Cordillera to the western slope. This change is mainly attributed to the scenario used and a greater humidity on the Pacific slope than on the Cauca slope.
Figure 2 shows altitudinal suitability as a probability of occurrence for present and future conditions for orchids in the five bioregions. Fifty percent of the areas under present conditions are concentrated in the altitudinal range of $900-1100 \mathrm{~m}$; however, for the 2030 climate change period, $50 \%$ of the data are concentrated between 1000 and $1300 \mathrm{~m}$, with $25 \%$ between 1300 and $1700 \mathrm{~m}$. For the 2050 climate change period, $50 \%$ of the data is concentrated between 1200 and 1500 $\mathrm{m}$, with $25 \%$ between 1500 and $1800 \mathrm{~m}$. Evidence of a shift towards higher areas of elevation in all the bioregions is evident when comparing periods.

Changes in spatial and temporal distribution - The results of the model generated with $p>0.61$ project a drastic decline in suitability for orchids in all TDF areas in Colombia. The nearly $1,000,000$ ha that are TDF orchids currently potential suitable area would be reduced to less than 240,000 ha during the 2050 period (see Table 5 and Figure 3).). 
TABLE 5: Extent (ha) based on suitability ( $p>0.61$ ) for orchids of the Tropical Dry Forest (TDF) in Colombia. The values are discriminated by bioregions and departments for three periods (Present, 2030 and 2050). *minimum extent.

\begin{tabular}{|c|c|c|c|c|c|}
\hline \multirow{2}{*}{ Bioregion } & \multicolumn{3}{|c|}{ Hectares } & \multicolumn{2}{|c|}{ Net gain/loss (Hectares) } \\
\hline & Present & 2030 & 2050 & 2030 & 2050 \\
\hline \multicolumn{6}{|l|}{ Cauca River Valley } \\
\hline Antioquia & 13,038 & 19,773 & 18,909 & 6735 & 5871 \\
\hline Caldas & 173 & 0 & 0 & -173 & -173 \\
\hline Quindío & 28,666 & 5353 & 2245 & $-23,313$ & $-26,421$ \\
\hline Risaralda & 20,032 & 0 & 0 & $-20,032$ & $-20,032$ \\
\hline Cauca Valley & 493,280 & 166,038 & 106,979 & $-327,242$ & $-386,301$ \\
\hline Subtotal & 555,189 & 191,164 & 128,133 & $-364,025$ & $-427,056$ \\
\hline \multicolumn{6}{|l|}{ Caribbean Region } \\
\hline Atlantic & 259 & 0 & 0 & -259 & 259 \\
\hline Bolívar & 2159 & 0 & 0 & -2159 & 2159 \\
\hline Cesar & 6476 & 18,737 & 6735 & 12,261 & -259 \\
\hline Córdoba & 2849 & 0 & 0 & -2849 & 2849 \\
\hline La Guajira & 1813 & 2936 & 86 & 1123 & -1727 \\
\hline Magdalena & 18,391 & 4576 & 86 & $-13,815$ & $-18,305$ \\
\hline Sucre & 14,074 & 173 & 0 & $-13,901$ & $-14,074$ \\
\hline Subtotal & 46,021 & $26,422^{*}$ & $6,907^{*}$ & $-19,599$ & $-39,114$ \\
\hline \multicolumn{6}{|l|}{ Magdalena Valley } \\
\hline Cundinamarca & 70,543 & 29,184 & 45,762 & $-41,359$ & $-24,781$ \\
\hline Huila & 68,816 & 20,204 & 11,570 & $-48,612$ & $-57,246$ \\
\hline Tolima & 17,700 & $9152^{*}$ & $7080^{\star}$ & -8548 & $-10,620$ \\
\hline Subtotal & 157,059 & 58,540 & 64,412 & $-98,519$ & $-92,647$ \\
\hline Patía Valley & & & & 0 & 0 \\
\hline Cauca & 57,246 & 23,399 & 21,759 & $-33,847$ & $-35,487$ \\
\hline Nariño & 7253 & $950^{*}$ & $0^{*}$ & -6303 & -7253 \\
\hline Subtotal & 64,499 & $24,349^{\star}$ & $21,759^{\star}$ & $-40,150$ & $-42,740$ \\
\hline \multicolumn{6}{|l|}{ Santander } \\
\hline North of Santander & 8548 & 21,500 & 6907 & 12,952 & -1641 \\
\hline Santander & 130,033 & 28,148 & 6303 & $-101,885$ & $-123,730$ \\
\hline Subtotal & 138,581 & 49,648 & $13,210^{*}$ & $-88,933$ & $-125,371$ \\
\hline Total & 961,349 & 350,123 & 234,421 & $\begin{array}{c}0 \\
-611,485\end{array}$ & $\begin{array}{c}0 \\
-727,187\end{array}$ \\
\hline
\end{tabular}

A reduction of $63.3 \%(-609,196$ ha) suitability is is 26,422 ha, and in the Patía Valley, 24,349 ha for expected for the 2030 period compared to the present, the 2030 period. For the 2050 period, the minimum and a reduction of $75.6 \%(-724,878$ ha) for 2050. The suitability for the Caribbean Region is $6907 \mathrm{ha}$; for the minimum suitability area in the Caribbean Region Santander region, 13,210 ha; and for the Patía Valley, 

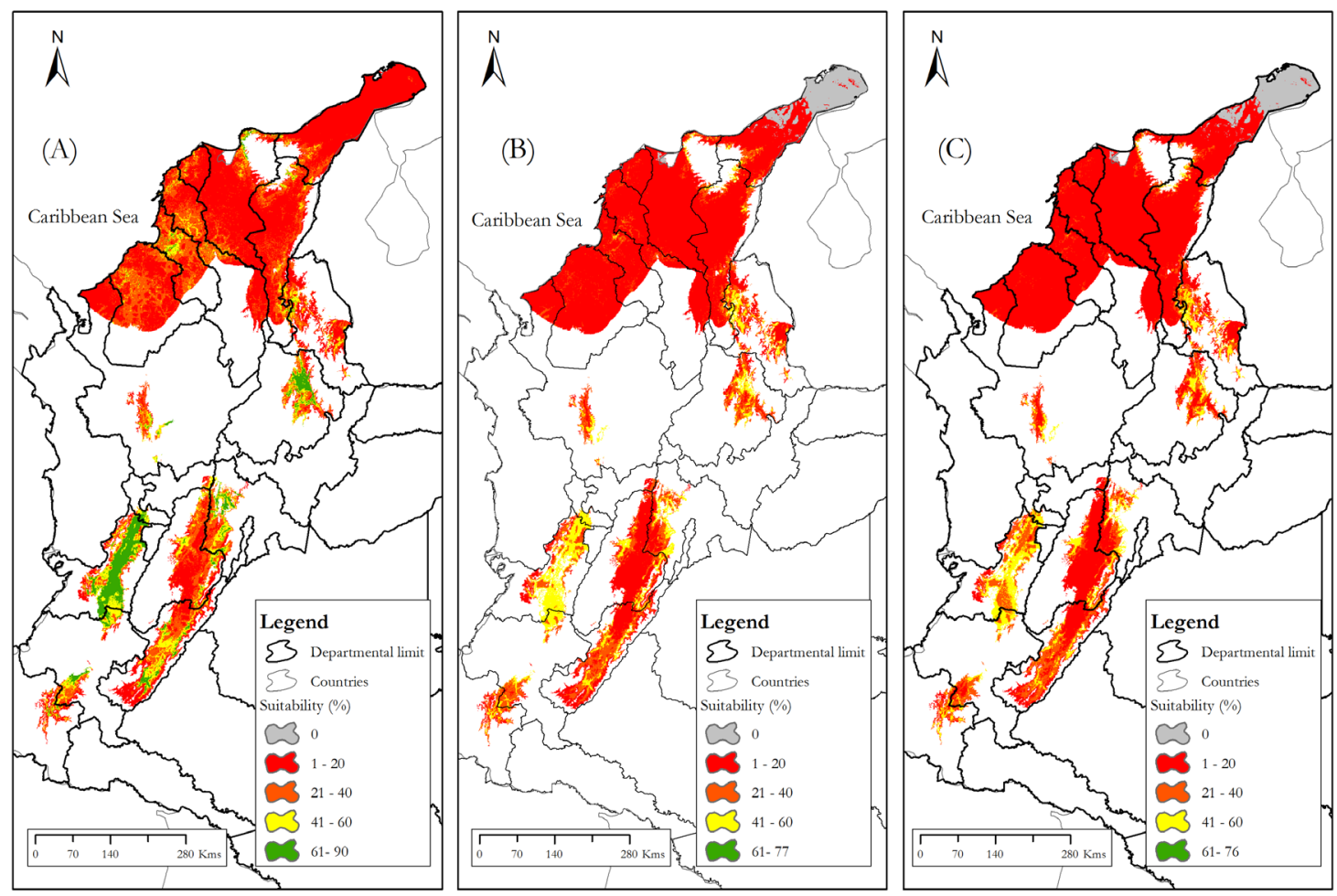

FIgure 3. Suitability of Tropical Dry Forest (TDF) in Colombia for 12 studied orchid species. A) Present, B) 2030 and C)

2050. Red indicates areas of lower suitability and green areas of greater suitability.

21,759 ha. The values for each bioregion and the departments they comprise are shown in Table 5. The particularities and highlight events of every bioregion are discussed in Appendix 4.

Bioclimatic niches a bet for the future - The bioclimatic niches proposed here are areas that include: a) suitable areas $(p>0.61)$ for the future according to our model; b) areas that maintain patches of TDF within or nearby (less than $23 \mathrm{~km}$ ); c) public or private currently protected areas (PA and NRCS) within or nearby (less than $23 \mathrm{~km}$ ). The climatic niches would be suitable as a thermal refuges and for the altitudinal migration of flora and fauna of an area or bioregion under climate change conditions. The set of present and suitable areas, as well as the spatiotemporal ecological dynamics that occur there, would constitute this new landscape management unit. Since their inception, they are integrated into altitudinal migration corridors (AMC; see Reina-Rodríguez et al. 2016) and are susceptible to monitoring and management by the environmental authorities.
In Colombia, 45 basins with bioclimatic niches for the TDF ecosystem were detected at $p>0.61$, as shown in Table 4 and figure 4, which include 609 TDF polygons, with 52 public protected areas (PA) and 30 private protected areas (NRCS), located between 0 and $1798 \mathrm{~m}$ and spreading on 187,604 ha. Due to the lack of protected areas with the traits above mentioned in the Caribbean and Patía Valley bioregions, eight more areas are proposed. These areas share abiotic characteristics such as steep slopes, rock formations or relief forms that are unsuitable for agriculture and livestock, forming natural barriers for the permanent establishment of TDF cover. A total of 69 bioclimatic niches (45 net areas, 16 complementary and 8 below the threshold $p=0.61$ ) (see figure 4 ), based on the concept are listed in Appendix 5, and more information of interest for its management.

For the Cauca River Valley, 13 basins with $p>0.61$ for the occurrence of bioclimatic niches are proposed, which showed proximity to $239 \mathrm{TDF}$ polygons, 25 PA and 23 NRCS less than $23 \mathrm{~km}$ away, lying within the altitudinal ranges of 629-1796 m (see Table 4 and 


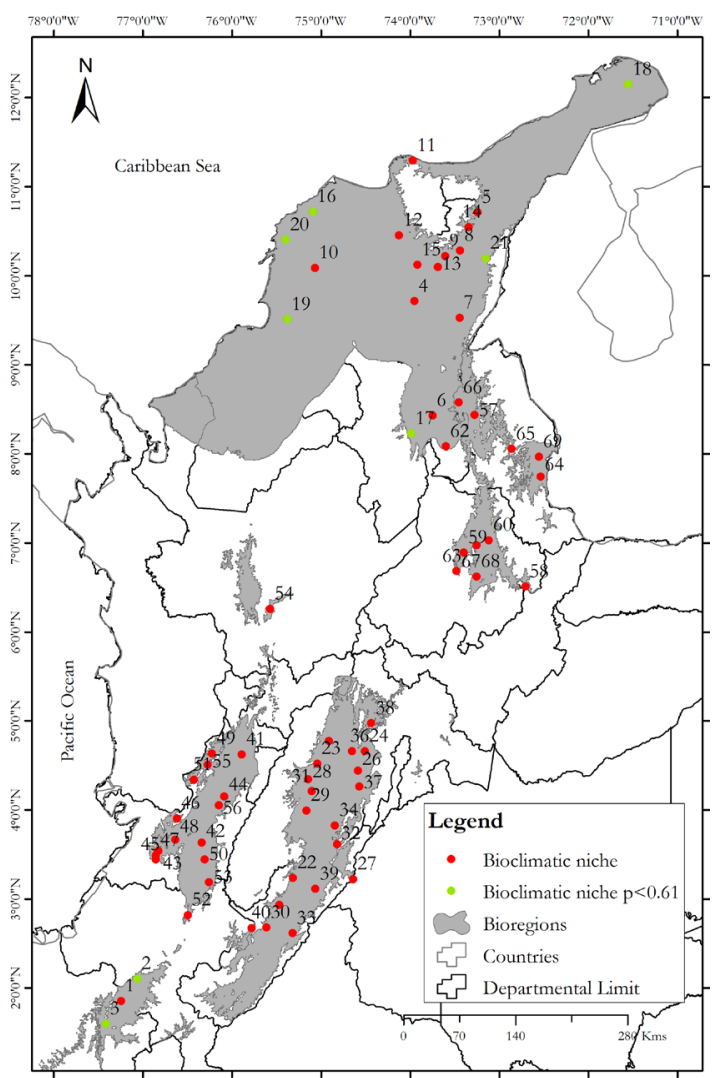

FIgURE 4. Locations of basins with the presence of bioclimatic niches and complementary areas with $p<0.61$ based on modelling of Tropical Dry Forest (TDF) orchids for the period 2050 .

Appendix 3). These data target areas for management and conservation under climate change conditions. TDF orchids with narrow altitudinal distribution such as Encyclia betancourtiana Carnevali \& I. Ramírez, E. chloroleuca (Hook) Neumann and Pleurothallis aryter Luer, as well as endemics or those at the maximum of their altitudinal distribution such as Cattleya quadricolor Lindl., Catasetum tabulare and Vanilla calyculata, would require special monitoring under climate change.

Important areas for the future conservation of these plants will be on both slopes of the Western Cordillera and on the eastern slope of the Central Cordillera of the Cauca and Risaralda Valley, as well as on the northern flank of the Western Cordillera in the department of Antioquia (see Appendix 3). Maintaining connectivity is essential between the orchid flora of the Chocó biogeographic region and the Andes through the relict, sub-xerophytic, sub-Andean forest-dry shrubland forest existing on both slopes of the Western Cordillera, especially to conserve the richness of these plants, the existing endemics and the gene flow occurring there. New species recently described and others under study (García-Ramírez \& García-Revelo 2013, Leopardi et al. 2014) justify management strategies and investment in conservation.

For the Caribbean bioregion, 8 basins are proposed with $p>0.61$ for the occurrence of bioclimatic niches, mainly along the three slopes of the Sierra Nevada de Santa Marta, with close to 91 polygons of TDF, but these polygons include no PA and only two NRCS (private areas) at less than $23 \mathrm{~km}$; the altitude ranges from 0-1485 m (see Table 4 and Appendix 3). Because of the low suitability of the Caribbean bioregion, the consideration of the six areas below the established threshold of $p=0.61$ is reasonable. This would include the rolling hills and limestone cliffs up to $800 \mathrm{~m}$ such as the Montes de María between the Sucre and Córdoba departments, which have suitability values of $p=0.26$; the precoastal hills of the Cartagena de Indias at $170 \mathrm{~m}$ with $p=0.07$; the Serranía de Piojó (Atlantic) with elevations up to $350 \mathrm{~m}$ and $p=0.13$; the Serranía de San Lucas (Bolívar) with altitude ranging from 60-1617 $\mathrm{m}$ and $p=0.02$; the Serranía de Macuira with altitude up to $1000 \mathrm{~m}$ (Guajira) and $p=0.0$; the Serranía de Perijá (Cesar) with $p=0.03$; and the northern part of the Western Cordillera (ex. PNN Paramillo, Córdoba), which has a wide altitudinal range of 350-3960 m, as well as the presence of important phorophytes for orchids of the bioregion such as Anacardium excelsum (Bertero ex Kunth) Skeels, Brosimum alicastrum Sw., Pseudobombax septenatum (Jacq.) Dugand, Guazuma ulmifolia, Samanea saman and Attalea butyracea (Mutis ex L.f.) Wess.Boer (Patiño-Uribe et al. 2002, Sugden 1981). The presence of threatened fauna such as the cotton-top tamarin Saguinus oedipus L., endemic to Colombia and categorized as critically endangered (CR) (Savage \& Causado 2008), demonstrates the enormous value of these areas for conservation purposes and that they have sufficient weight for being proposed as sites for bioclimatic niches in the Caribbean region. Orchids of importance in the area include Encyclia cordigera (Kunth) Dressler, Cyrtopodium paniculatum and Trichocentrum nudum (Bateman ex Lind1.) M.W. Chase \& N.H. Williams, as well as others with a more restricted distribution such 
as Mormodes cartonii Hook., which would require special monitoring under climate change conditions.

For the Magdalena Valley bioregion, 15 basins with $p>0.61$ for the occurrence of bioclimatic niches are proposed. This is the highest value in Colombia and has 157 TDF polygons, 16 PA and four NRCS less than $23 \mathrm{~km}$ away and within the altitudinal range of 237-1790 m (see Table 4 and Appendix 3). Magdalena Valley has the following preferred phorophytes for orchids: Anacardium excelsum, Attalea butyracea, Guazuma ulmifolia, Albizia guachapele (Kunth) Dugand, Samanea saman, Calliandra pittieri, Guarea guidonia (L.) Sleumer, Machaerium capote Dugand and Trichilia pallida Sw. (Pizano \& García 2014). The valley also has a significant number of basins with areas suitable for bioclimatic niches along both the western slope of the Eastern Cordillera and the eastern slope of the Central Cordillera. All of these basins hold the possibility of a migration event. Representative orchids in the area are Dimerandra emarginata (G. Mey.) Hoehne and other endemics such as Mormodes theiochlora (Rchb.f.) Salazar, Trichocentrum aguirrei (Königer) M.W. Chase \& N.H. Williams, Epidendrum mutisii Hágsater and E. rodrigoi Hágsater, which would require special monitoring under climate change.

For the Patía Valley, only one basin was detected with $p>0.61$ for the occurrence of bioclimatic niches. This is the lowest value for all Colombia. The basin consists of ten polygons of TDF, and not a single PA nor NRCS are located within $23 \mathrm{~km}$ distance, with altitude ranging from $612-1443 \mathrm{~m}$ (see Table 4 and Appendix 3). Public and private protected areas are lacking, few plant inventories are available, and the State has an incipient presence at all levels.

For now, prospects for orchid conservation indicate that only natural geographic barriers exist in this territory, and these are present in specific locations with rocky massifs, which are found at the centre, north and south of the Patía Valley, showing suitability values of $p=0.31$; the dry canyons of Guáitara-Juanambú $(p=0.32)$ are lower than our threshold but have steep slopes and altitudinal gradients that favour the conservation of these plants. The presence of the phorophytes preferred by orchids was recorded by our field team in these places between 500 and 1500 m; these include Erythrina poeppigiana (Walp.) O.F. Cook, Ficus obtusifolia Kunth, Samanea saman (Jacq.) Merr., Guapira costaricana (Standl.)
Woodson, Inga spectabilis (Vahl) Willd., Psidium sartorianum (O. Berg) Nied., P. guajava L., Calliandra pittieri Standl., Crescentia cujete L., Guazuma ulmifolia Lam. and Eugenia sp. The 2013 Patía Expedition recorded the southernmost populations of Catasetum tabulare Lindl., which is endemic to Colombia, and the Cauca guan Penelope perspicax Bangs (Class Aves, Phylum Chordata), which had not been recorded for more than 25 years in the bioregion. This demonstrates the value of these areas for conservation purposes and lends sufficient weight for these sites to be proposed as bioclimatic niches of flora and fauna in the Patía bioregion.

For the Santander bioregion, 8 basins with $p>0.61$ for the occurrence of bioclimatic niches were found. These niches showed proximity to 112 TDF polygons, $11 \mathrm{PA}$, no NRCS less than $23 \mathrm{~km}$ away and altitudinal ranges of 154-1798 m (see Table 4 and Appendix 3). The field team recorded phorophytes in the range of 730-1200 m, including Anacardium excelsum, Machaerium capote, Guarea guidonia, Psidium guajava L., Calliandra magdalenae (DC.) Benth., Clusia alata Planch. \& Triana, Hura crepitans L., Crescentia cujete, Guazuma ulmifolia, Ficus insipida Willd. and Eugenia sp.; endemic orchid species of TDF such as Catasetum lucis P. Ortiz \& G. Arango, Catasetum tricorne P. Ortiz and Phragmipedium manzurii W.E. Higgins \& Viveros, (Martínez et al. 2015); and birds in the IUCN threatened category such as the Blue-billed Curassow Crax alberti Fraser (CR), Niceforo's Wren Thryothorus nicefori Meyer de Schauensee (EN), and Chestnut-bellied Hummingbird Amazilia castaneiventris Gould (EN), among others (Donegan et al. 2010). The prospects for conservation of this bioregion are greater due to the existence of public protected areas, contiguity with more humid life zones (ex. Yariguíes National Park with continuous canopy at altitudes $>1500 \mathrm{~m}$ ) and TDF at intermediate altitudes, which increase the probability of their occurrence.

\section{Discussion}

Geographic gaps -. Large gaps of geographic information of these orchids are present in all areas of TDF in Colombia. The overlap in genera and species richness between the national listings (Pizano \& García 2014) and the Cauca River Valley bioregion 
TABLE 6: Suitability indices for the 2030 and 2050 periods in five areas of Tropical Dry Forest (TDF) in Colombia. Relative to the size of the TDF in Colombia: IoBsT_30 and IoBsT $T_{30}$; size in the bioregion: IoBioreg $_{30}$ and IoBioreg $_{50}$; and severity: $I o S h p_{30}$ and $I o S h p_{50}$. Values in bold are higher than the average for that index.

\begin{tabular}{|c|c|c|c|c|c|c|}
\hline Bioregion & $I o B s T_{30}$ & $I O B s T_{50}$ & loBioreg $_{30}$ & loBioreg $_{50}$ & loShp $p_{30}$ & $\operatorname{loSh} p_{50}$ \\
\hline Cauca River Valley & 19.9 & 13.3 & 3.4 & 2.3 & 2.9 & 4.3 \\
\hline Caribbean Region & 2.7 & 0.7 & 5.7 & 1.5 & 1.7 & 6.7 \\
\hline Magdalena Valley & 6.1 & 6.7 & 3.7 & 4.1 & 2.7 & 2.4 \\
\hline Patía Valley & 2.5 & 2.3 & 3.8 & 3.4 & 2.6 & 3.0 \\
\hline Santander Region & 5.2 & 1.4 & 3.6 & 1.0 & 2.8 & 10.5 \\
\hline
\end{tabular}

(Reina-Rodríguez et al. 2010) demonstrates that current knowledge is far from reality. The difficult logistics of collecting orchids, as well as omission by collectors who are not specialists in this group, have hindered their presence being recorded. While it is true that our data do not represent $100 \%$ of the orchids in the ecosystem, they do provide an estimate of the geographical gaps of these plants in TDF areas. There are 314 municipalities with influence in the TDF areas in Colombia. Our data for the 12 "core" species support the presence of these orchids in 118 municipalities (see Appendix 6). In other words, slightly more than half of the municipalities $196(62,4 \%)$, do not have records, mainly the departments of Cesar, Bolívar, Atlántico, Nariño, Cauca, Caldas, Córdoba, Sucre, Huila and Cundinamarca, suggesting important geographical information gaps. Greater effort in rethinking national and regional strategies is needed to fill in these geographical gaps.

Lowland-highland altitudinal migration - . Altitudinal and latitudinal migrations have occurred during the glacial and interglacial periods; however, current extinction rates are 1000 times the background rate (Pimm et al. 2015). A progressively warmer climate would induce these plants to migrate, probably vertically from low-lying areas to higher areas (Foster 2001). Recent studies support this hypothesis in Peru (Feeley et al. 2011, Lutz et al. 2013), Venezuela (Safont et al. 2012) and Colombia (Reina-Rodríguez et al. 2016). The data herein supported estimates of altitudinal changes of $177.5 \mathrm{~m}$ (present-2030) and $379.8 \mathrm{~m}$ (present-2050) for the 12 focal species. In the case of TDF orchids, the greatest impediment to ascending the mountains is the availability of suitable habitat due to habitat fragmentation, land use and the extraction of phorophytes in mid-mountain areas.
Undoubtedly, this condition limits the dispersal of orchids from lowland areas. The possibilities of success and responses to thermal (low altitude) and water stress may vary according to the degree of specialization that varies between species (Laurance et al. 2011, Stevens 1992, Hsu et al. 2014, ReinaRodríguez et al. 2016) and the intrinsic resistance capabilities linked to their evolutionary history (Darwin 1872). Further studies focused on genotypic and physiological responses of these plants would be desirable in the short term. Preventive measures are urgently required due to the limited availability of habitat and land use in the mountainous areas north of the Andes (Young \& Lipton 2006). The assemblage between bioclimatic niches $(\mathrm{BN})$ proposed here and Altitudinal Migrations Corridors AMC, planned dispersal routes that connect forest relics through a gradient of thermal, edaphic, and moisture and will play an important role in the adaptation and altitudinal displacement of orchids caused by Climate Change (Reina-Rodríguez et al. 2016). The establishment of AMC, included the enrichment and management of phorophytes and the use of protective riverine forest of $30 \mathrm{~m}$ or more (Law 1449/1977). It also covered public protected areas (PA), such a Natural Parks, and private protected areas such as Natural Reserves of Civil Society (NRCS) stipulated in Colombian legislation (Law 2372/2010); all of these are included in the National System of Protected Areas (NSPA, in Spanish SINAP). These areas would function as nodes of altitudinal connectivity and are fundamental units of the landscape to facilitate orchid dispersal. The spatiotemporal dynamic and interspecific relationships of biodiversity have recurrently been ignored. However, we in section 4.4 have analyzed some complementary factors not included in the current models. 
Where will the orchids be found in the future? - . The areas and associated maps show a drastic reduction in areas of suitability due to climate change in the two periods and the five bioregions examined. The loss of suitable areas is especially evident in the Caribbean, the Santander and the Patía River Valley regions as shown in Figure 1. However, in terms of extent, the IoBsT index (see Table 6, available only electronically as supplemnetal material at: http://www.lankesteriana.org/ Lankesteria-naJournal/17(1)/reina\%20rodriguez $\% 20$ et\%20al\%202017\%20appendix6.pdf), identifies the Cauca River Valley as the bioregion with the greatest loss of suitability for both future periods, showing reduction to one-quarter (1/4) of its present size, while the IoBioreg index shows that the most significant regional losses will occur inside the Caribbean region, which will be reduced to one-sixth (1/6) of its present extent. However, the IoShp index shows that change will occur with the greatest severity in the Santander region, where the area will be reduced to one-tenth $(1 / 10)$ of the present area. The minimum suitability values suggest that the Caribbean and Patía Valley bioregions are the most critical in the country.

Suitability for the 2050 period will disappear from the following departments: the Atlantic, Bolívar, Sucre and Córdoba departments in the Caribbean bioregion; the department of Nariño in the Patía Valley bioregion; and the department of Risaralda in the Cauca River Valley bioregion. Meanwhile, the Cauca Valley department of the Cauca River Valley bioregion, the Cundinamarca department of the Magdalena Valley bioregion and the Cauca department of the Patía Valley bioregion will maintain the highest suitability for this period.

Results from the model suggest that many areas, especially from the Caribbean Plains and the Patía Valley, will not be suitable following the changes that lie ahead (see Appendix 3). Flat areas below $600 \mathrm{~m}$ without elevation gain within $50 \mathrm{~km}$ of populated centres of more than 50,000 inhabitants are characteristics that may lead to the eventual loss of suitability in the next 50 years. Temperature increases, decreased water availability, and the long distances required for migration to higher altitudes are all risk factors for the survival of these plants. Greater efforts and national conservation strategies of TDF should focus on these areas, specifically in the basins and complementary areas shown in Appendix 3.
Bioclimatic niches, pollinators and mycorrhizae -. The spatiotemporal dynamic and interspecific relationships of biodiversity have recurrently been omitted in previous studies. Biotic and abiotic factors exist at the margins of the current tools being used and are worth considering when preparing the new generation of models with greater biological realism, which will include interactions, types of dispersion and evolutionary patterns that will improve the accuracy of predictions (Urban 2015). This study evaluated several factors for assigning bioclimatic niches $a$ posteriori as a landscape management unit and as a new spatiotemporal management strategy.

According to the database of Insect Collection of the Museum of Entomology of the Valley University (2013), available at http://ipt.sibcolombia.net/valle/ resource.do? $\mathrm{r}=$ insectos-universidad-del-valle, insect pollinators are present in TDF areas of Colombia across wide altitudinal gradients from $0-2800 \mathrm{~m}$, favouring cross-pollination and dispersal processes. These pollinators can travel up to $23 \mathrm{~km}$ in the five bioregions, which include 609 TDF polygons, 52 public protected areas (PA) and 30 private protected areas (NRCS) that are located between 0 and $1798 \mathrm{~m}$ on 187,604 ha distributed in 45 basins throughout the country; thus, the potential exists for this proposal to be feasible throughout the country. Nonetheless, some areas at altitudes below the threshold generated by the model had abrupt relief-forming natural barriers that prevent the establishment of urban areas, mechanized agriculture or other types of exploitation. This condition allows the establishment of plant cover that creates a microclimate suitable for the establishment of the phorophytes, mycorrhizae, pollinators and dispersers necessary for the occurrence of Orchidaceae. Populations of Catasetum tabulare with fruits were observed in the pyroclastic massifs in the north-east and centre of the Patía Valley, confirming the presence of these pollinators and the quality of the ecosystem. In the Caribbean bioregion, areas with these characteristics are also present in the precoastal hills close to Cartagena de Indias (100 m), Serranía del Piojo, Serranía de Macuira (735 m), Serranía de San Lucas $(1617 \mathrm{~m})$ and Montes de María (570 $\mathrm{m})$, making their inclusion as bioclimatic niches acceptable, given the absence of protected areas in these bioregions. 
Little is known about the survival of mycorrhizal fungi and their spatiotemporal variations when faced with an increase in average temperature in Colombia of $2.6^{\circ} \mathrm{C}$. However, physiognomically well-structured and conserved forests greater than 10 ha can be assumed to have a microclimate suitable for containing the mycorrhizae necessary for orchid germination. The presence of at least three of the major phorophytes of these plants (see Table 2) was corroborated in the field in $25 \%$ of the bioclimatic niches presented here.

\section{Conclusions and recommendations}

In this paper we provide a complementary vision based on the presence of living organisms that are intrinsic parts of the ecosystem. The results suggest a significant loss of areas of suitability due to climate change by bioregions and periods (present-2030, present-2050 and 2030-2050). The Santander region, the Caribbean region and the Cauca River Valley will lose much of their present extent of suitability. An altitudinal displacement, which was not uniform, was also detected in the five studied bioregions. Foothills with altitudes of $1165.4 \mathrm{SD} \pm 222.6$ will have greater suitability for the 2030 period, and the areas of foothills with altitudes of $1364.1 \mathrm{SD} \pm 195.1$ will have greater suitability for the 2050 period.

In this sense, the model results reinforce the hypothesis of migration of TDF orchids in the northern part of South America, where there has been an increase in altitudinal suitability of the orchids of TDF lowlands towards the mid-mountain areas in the Colombian Andes.

Euglossini bees, vectors of cross-pollination in orchids, are present in both TDF areas and in moist forests at a wide range of altitudes. Their ability to thermoregulate and fly long distances even in dry environments is one of the key biotic elements that enable this altitudinal migration.

The results highlight the importance of articulating complementary spatiotemporal dynamic conservation strategies compared to current and static protected areas. Herein, a new landscape management unit bioclimatic niche was defined, which combines the current ecologically valuable coverages of ecosystems and their future areas of suitability. Several biotic and abiotic variables not collected for the actual generation of models have been included in the analysis. In total,
69 areas were proposed as bioclimatic niches, becoming the first national approximation to use living organisms to complement technical criteria in decision-making for land-use planning under climate change conditions. The identification of these bioclimatic niches serves as an early warning for focusing resources and efforts on these areas and altitudinal ranges. In the short term and at a detailed scale, design, implementation and articulation are required between the bioclimatic niches proposed here and supported by the model with $\mathrm{AMC}$ and the public and private protected areas in TDF in Colombia. The inclusion of some areas with $p<0.61$ and abrupt relief are the only guarantee of conservation of orchids in the Caribbean region, and the Patía Valley is equally important, where the absence and low representation of orchids are evident. In terms of landuse management, bioclimatic niches should be included within restoration-reforestation plans, land-use plans (LUP), watershed management plans (WSMP) and approaches such as ecosystem-based adaptation (EbA) referred to in the national climate change policy. This task should be specifically undertaken in the short term by the regional autonomous corporations throughout Colombia as an adaptation measure to safeguard biodiversity.

The regional environmental authorities and agencies for the conservation of nature of the national and international order, as well as NGO's and local communities, are key actors in considering, implementing and adjusting the implementation of the conclusions supported herein and currently underway. Finally, evidence shows large geographical gaps of orchids in this ecosystem, especially in the Patía Valley, Caribbean region, and south of the Magdalena Valley, as well as in the inaccessible dry enclaves. However, new knowledge of their geographical distributions is becoming available through infrastructure projects established by the Colombian legislature.

AcKnowledgments. The funds for this project were sponsored by Agreement 14-12/117-14/0025-280CE of 2014 between the Alexander von Humboldt Biological Resources Research Institute and the Fundacion Universidad del Valle and the CI 4326 project of the Vice-Rectory of Research of the Universidad del Valle. Special thanks to UMATA (Anapoima, Cundinamarca), the University of Barcelona, and the Anonymous Society Colinas de San Simeón (Cartagena de Indias, Bolívar). Thanks also to the 
people with whom we directly or indirectly collaborated: Diego Alejandro Castro; Francisco López-Machado; Isabel Nichols (Cali, Valle del Cauca); Jorge Meza (Bucaramanga, Santander); Alicia Rojas (Floridablanca, Santander); Hedy Saab Ramos (Montería, Córdoba); Jorge Contreras (Montería, Córdoba); Rosalba Ruiz Vega (Montería, Córdoba); Hernando Gómez (Sincelejo, Sucre); Pedro José Álvarez (Sincelejo, Sucre); Felipe Ballesteros (Coello, Tolima); Álvaro Cogollo (Medellín, Antioquia); Eduino Carbonó (Santa Marta, Magdalena); Diego Yepes (Santa Marta, Magdalena); Humberto Mendoza (Villa de Leyva, Boyacá); Hernando García (Bogotá, Cundinamarca); Carolina Castellanos Castro (Bogotá, Cundinamarca); Bernardo Ramírez (Popayán, Cauca); Carlos Parra (Bogotá,
Cundinamarca); Philip Silverstone-Sopkin (Cali, Valle del Cauca); Mayra Erazo (Cali, Valle del Cauca); Eric Hágsater (México, D.F.); Elizabeth Santiago Ayala (México D.F.); José Luis Alanís (Tuxpan, México); Ana Milena Silva (Cali, Valle del Cauca); Marcelo di Bonito (Nottingham, United Kingdom); Cristina Bustos Roldán (Esplugas de Llobregat Barcelona, España); Ethan Reina-Rodríguez (Barcelona, Spain); Carmen Lozano (Anapoima, Cundinamarca); Javier Ocampo (Bogotá, Cundinamarca); Gonzalo González (Cartagena de Indias, Bolívar); Geovanny L. Rodríguez (El Bordo, Cauca); Jerry Rubio (El Bordo, Cauca) Gilberto Rivas (Puerto Nuevo, Nariño); Philip Silverstone-Sopkin (Cali, Valle del Cauca); Jana Rubiano; Mayo Rubiano (Dapa, Cauca Valley); and Julián A. Reyna Rodríguez (Cali, Valle del Cauca).

\section{Literature Cited}

Ackerman, J.D. (1983). Specifiity and mutual dependency of the orchid-euglossine bee interaction. Biological Journal of the Linnean Society, 20, 301-314.

Ariza, A., Isaacs, P. \& González-M., R. (2014). Mapa de coberturas de bosque seco tropical en Colombia (escala 1:100.000, 2.0v). Instituto de Investigaciones de Recursos Biológicos "Alexander von Humboldt" Ministerio de Ambiente y Desarrollo. 1 hoja cartográfica.

Armenteras, D., Rudas, G., Rodríguez, N., Sua, S. \& Romero, M. (2006). Patterns and causes of deforestation in the Colombian Amazon. Ecological indicators, 6, 353-368.

Austin, M. V. \& van Niel K. (2011). Improving species distribution models for climate change studies: Variable selection and scale. Journal of Biogeography, 38, 1-8.

Barbet-Massin, M., Jiguet, F., Albert, C. \& Thuiller, W. (2012). Selecting pseudo-absences for species distribution models: How, Where and How Many? Methods in ecology and evolution, 3(2), 327-338. Doi: 10.1111/j.2041-210X.2011.00172.x

Bates, B.C., Kundzewicz, Z.W., Wu, S. \& Palutikof, J.P. (2008). Climate Change and Water. Technical Paper of the Intergovernmental Panel on Climate Change, IPCC Secretariat, Geneva, $210 \mathrm{pp}$.

Becker, P., Moure, J.S. \& Peralta, F.J.A. (1991). More about euglossine bees in Amazonian forest fragments. Biotropica, 23, 586-591.

Bellard, C., Bertelsmeier, C., Leadley, P., Thuiller W. \& Courchamp, F. (2012). Impacts of climate change on the future of biodiversity. Ecological Letters, 15(4), 365377. Doi:10.1111/j.1461-0248.2011.01736.x.

Benzing, D. (1998). Vulnerabilities of tropical forests to climate change: The significance of resident epiphytes. In: A. Markham (Ed.), Potential impacts of Climate Change on Tropical Forest Ecosystems (pp. 379-400). The Netherlands: Springer Netherlands.

Bernal, R., Gradstein, R. \& Celis, M. (2015). Catálogo de Plantas y Líquenes de Colombia. Bogotá D.C., Cundinamarca, Colombia: Universidad Nacional de Colombia. (Accessed 04/20/2015 from http:// catalogoplantasdecolombia.unal.edu.co/catalog).

Berrío, J., Hooghiemstra, H., Marchant, R., \& RangelChacón, O. (2002). Late-glacial and Holocene history of the Dry forest area in the south Colombian Cauca valley. Journal of Quaternary science, 17(7), 667-682.

Berrío, J. C., Hooghiemstra, H., Behling, H., Botero, P. \& Van der Borg, K. (2002). Late-Quaternary savanna history of the Colombian Llanos Orientales from Lagunas Chenevo and Mozambique: a transect synthesis. The Holocene, 12, 35-48.

Betancur, J., H. Sarmiento-L., Toro-González, L. \& J. Valencia. (2015). Plan para el estudio y la conservación de las orquideas en Colombia. Ministerio de Ambiente y Desarrollo Sostenible; Universidad Nacional de Colombia, Bogotá D.C. 336 pp.

Bilton, M. C., Metz, J. \& Tielbörger, K. (2016). Climatic niche groups: A novel application of a common assumption predicting plant community response to climate change. Perspectives in Plant Ecology, Evolution and Systematics, 19, 61-69.

Camargo, E., Silva, V. \& Leit, E. (2006). Reproductive biology of two Cattleya (Orchidaceae) species endemic to north-eastern Brazil. Plant Species Biology, 21, 8591.

Chen, I. C., Hill, J. K., Ohlemueller, R., Roy, D. B. \& Thomas, C. D. (2011). Rapid range shifts of speices associated with high levels of climate warming. Science, 333, 1024-1026.

DANE. Departamento Administrativo Nacional de Estadística (2005). Censo 2005. Bogotá D.C., Cundinamarca, Colombia. (Accessed on 05/04/2015, from http://www.dane.gov.co/).

Darwin, Ch. (1872). The origen of species. 6a Edition. John Murray, London. 
Donegan T. M., Avendaño, J. E., Briceño, E. R., Luna, J. C., Roa, C., Parra, R., Turner, C., Sharp, M. \& Huertas B. (2010). Aves de la Serranía de los Yariguíes y tierras bajas circundantes, Santander, Colombia. Cotinga, 32, 72-89.

Dressler, R. L. (1982). Biology of the orchid bees (Euglossini). Annual Review of Ecology, Evolution, and Systematics, 13, 373-394.

Elith, J., Graham, C., Anderson, R., Dudik, M., Ferrier, S., Guisan, A., Hijmans, R. J., Huettmann, F., Leathwick, J. R., Lehmann, A., Li, J., Lohmann, L. G., Loiselle, B. A., Manion, G., Moritz, C., Nakamura, M., Nakazawa, Y., Overton, J. McC. M., Peterson, A. T., Phillips, S. J., Richardson, K., Scachetti-Pereira, R., Schapire, R. E., Soberón, J., Williams, S., Wisz, M. S. \& Zimmermann, N. E. (2006). Novel methods improve prediction of species distributions from occurence data. Ecography, 29(2), 129-151. Doi: 10.1111/j.2006.09067590.04596.x

Elith, J., Phillips, S., Hastie, T., Dudik, M., Chee, Y. \& Yates, C. (2011). A stadistical explanation of MaxEnt for ecologist. Diversity and Distributions, 17, 14-57.

Engler, R., Guisan, A. \& Rechteiner, L. (2004). An improved approach for predicting the distribution of rare and endangered species from occurrence and pseudoabsence data. Journal of Applied Ecology, 41, 263-274.

Etter, A., McAlpine, C. \& Possingham, H. (2008). A historical analysis of the spatial and temporal drivers of landscape change in Colombia since 1500. Annals of the American Association of Geographers, 98, 2-23.

Feeley, K., Silman, M., Bush, M., Farfan, W., GarciaCabrera, K., Malhi, Y., Meir, P., Revilla, N. S., Raurau Quisiyupanqui, M. N. \& Saatchi, S. (2011). Upslope migration of andean trees. Journal of Biogeography, 38, 783-791. Doi: 10.1111/j.1365-2699.2010.02444.x

Feeley, K. \& Silman, M. (2010). Land-use ande climate change effects on population size and extinction risk of Andean plants. Global change biology, 16, 3215-3222.

Foster, P. (2001). The potential negative impacts of global climate change on tropical montane cloud forests. Earth-Science Reviews, 55, 73-106.

García-Ramírez, D. A. \& García-Revelo, J. S. (2013). Diversidad de orquídeas de los bosques altos de la Serranía de los Parguas, Chocó biogeográfico, Colombia. Lankesteriana, 13 (1-2), 132.

González-Carranza, Z., Berrío, J., Hooghiemstra, H., Duivenvoorden, J. \& Behling, H. (2008). Changes of seasonally dry forest in the Colombia Patía Valley duringe the early and middle Holocene and development of a dry climatic record for the northernmost Andes. Review of paleobotany and palynology, 152, 1-10.

Gutiérrez-Rey, H. J. (2002). Aproximación a un modelo para la evaluación de la vulnerabilidad de las coberturas vegetales de Colombia ante un posible cambio climático utilizando SIG. Meteorología Colombiana, 6, 55-63.

Hansen, M., Popatov, P., Moore, R., Hancher, M., Tarubanova, S., Tyukavina, A., Thau, D., Stehman, S. V., Goetz, S. J., Loveland, T. R., Kommareddy, A., Egorov, A., Chini, L., Justice, C. O. \& Townshend, J. R. G. (2013). High-Resolution Global Maps of 21stCentury Forest Cover Change. Science, 342(6160), 850-853. Doi: 10.1126/science. 1244693

Harris, L. (1984). The Fragmented Forest: Island Biogeography Theory and the Preservation of Biotic Diversity. University of Chicago Press, Chicago, IL.

Hernández, P., Graham, C., Lawrence, L. \& Albert, D. (2006). The effect of sample size and species characteristics on performance of different species distribution modeling methods. Ecography, 29, 773-785.

Hernández-Camacho, J. \& Sánchez, P. (1992). Biomas Terrestres de Colombia. En: G. Halffter (Ed.), La diversidad Biológica de iberoamérica I (pp. 153-190). México D.F.: CYTED-D. Programa iberoamericano de ciencia y tecnología para el desarrollo. Instituto de Ecología.

Hijmans, R. J., Cameron, S. E., Parra, J. L., Jones P. G. \& Jarvis, A. (2005). Very High resolution interpolated climate surfaces for global land areas. International Journal of climatology, 25, 1965-1978.

Hijmans, R., Van Etten, J., Cheng, J., Mattiuzzi, M., Summer, M., Greenberg, J., Perpina, O., Bevan, A., Racine, E. B. \& Shortridge, A. (2012). CRAN R. (Downloaded on 08/10/2015 from http://cran.rproject.org/web/packages/ raster/raster.pdf)

Hsu, R., Wolf, J. \& Tamis, W. L. (2014). Regional and elevational patterns in vascular epiphyte richness on an east Asian island. Biotropica, 46(5), 549-555.

Ibáñez, I., Clark, J. S., Dietze, M. C., Feeley, K., Hersh, M., Ladeau, S., Mcbride, A., Welch, N. E. \& Wolosin, M. S. (2006). Predicting biodiversity change: outside the climate envelope, beyond the species-area curve. Ecology, 87(8), 1896-1906.

IDEAM, PNUD, MADS, DNP, CANCILLERÍA. (2015). Nuevos Escenarios de Cambio Climático para Colombia 2011-2100. Herramientas Científicas para la Toma de Decisiones- Enfoque Nacional - Departamental: Tercera Comunicación Nacional de Cambio Climático.

Isaac, J. L., Van der wal, J., Jhonson, C. N. \& Williams, S. E. (2009). Resistance and resilience: Quantifying relative extinction risk ina diverse assemblage of Australian tropical rainforest vertebrates. Diversity and Distributions, 15, 280-288.

IPCC. Panel Intergubernamental de Cambio Climático. (2013). Cambio climático. Base de ciencia física. Suiza: IPCC. $222 \mathrm{pp}$.

Janzen, D.H. (1971). Euglossine Bees as long-distance 
pollinators of tropical plants. Science, 171(3967), 203205.

Janzen, D.H. (1974). The deflowering of Central America. Journal of Natural History, 83, 48-53.

Jarvis, A., Rubiano, J. \& Cuero, A. (2004). Comparison of SRTM derived DEM vs. topographic map derived DEM in the region of Dapa. International Center for Tropical Agriculture CIAT.

Laurance, W. F., Useche, C., Shoo, L. P., Herzog, S. K., Kessler, M., Escobar, F., Brehm, G., Axmacher, J. C., Chen, I-C., Arellano Gámez, L., Hietz, P., Fiedler, K., Pyrcz, T., Wolf, J., Merkord, C. L., Cardelus, C., Marshall, A. R., Ah-Peng, C., Aplet, G. H., Arizmendi, M. d. C., Baker, W. J., Barone, J., Brühl, C. A., Bussmann, R. W., Cicuzza, D., Eilu, G., Favila, M. E., Hemp, A., Hemp, C., Homeier, J., Hurtado, J., Jankowski, J., Kattán, G., Kluge, J., Krömer, T., Lees, D. C., Lehnert, M., Longino, J. T., Lovett, J., Martin, P. H., Patterson, B. D., Pearson, R. G., Peh, K. S.-H., Richardson, B., Richardson, M., Samways, M. J., Senbeta, F., Smith, T. B., Utteridge, T.M.A., Watkins, J. E., Wilson, R., Williams, S. E. \& Thomas, C. D. (2011). Global warming, elevational ranges and the vulnerability of tropical biota. Biological Conservation, 144, 548-557. Doi: http://dx.doi.org/10.1016/j.biocon.2010.10.010

Leopardi-Verde, C., Reina-Rodríguez, G.A., Carnevali, G. \& Romero-González, G. (2014). Two new greenish Encyclia: E. parkeri and E. silverarum (Laeliinae, Orchidaceae). Phytotaxa, 183(3), 159-170.

Liu, C., White, M. \& Newell, G. (2013). Selecting thresholds for the prediction of species ocurrence with presenceonly data. Biogeography, 40, 778-789.

Lloret, F., Peñuelas, J., Prieto, P., Llorens, L. \& Estiarte, M. (2009). Plant community changes induced by experimental climate change:seedling and adult species composition. Perspectives in Plant Ecology, Evolution and Systematics, 11, 53-63. Doi: http://dx.doi. org/10.1016/j.ppees.2008.09.001

Lutz, D. A., Powell, R. L. \& Silman, M. R. (2013). Four decades of Andean timberline migration and implications for biodiversity loss with climate change. Plos One, 8(9), e74496. Doi: 10.1371/journal.pone.0074496

Marchant, R., Berrío, J. C., Behling, H., Boom, A. \& Hooghiemstra, H. (2006). Colombian dry moist forest transitions in the Llanos Orientales - a comparison of model and pollen-based biome reconstructions. Palaeogeography, Palaeoclimatology, Palaeoecology, 234(1), 28-44.

Martínez, S., Bonilla, M. \& López, H. (2015). Listado de la flora orchidaceae de Santander y comentarios sobre sus especies endémicas. Revista facultad de ciencias básicas Universidad militar nueva granada, 11(2), 54-111.
May, M.L. \& Casey, T.M. (1983). Thermorregulation and heat exchange in euglossine bees. Physiological Zoology, 56, 541-551.

Mcgarigal, K. \& Marks, B.J. (1995). Fragstats: spatial pattern analysis program for quantifying landscape structure. Gen. Tech.REP. PNW-GTR-351. Portland, Oregon: U.S. Department of Agriculture, Forest Service, Pacific Northwest Research Station, 122p.

Merow, C., Smith, M. \& Silander, J. (2013). A practical guide to MaxEnt for modeling species distributions: what it does, and why inputs and settings matter. Ecography, 36, 1058-1070.

Montgomery, D., Peck, E. A. \& Vining, G. (2006). Introducción al análisis de regresión lineal (pp.106108). México D.F.: Editorial Continental.

Monserud, R.A. \& Leemans, R. (1992). Comparing global vegetation maps with the Kappa statistics. Ecological Modelling, 62, 275-293.

Mooney, H., Bullock, S. \& Medina, E. (1995). Seasonally Dry Tropical Forests. Cambridge, Reino Unido: Cambridge University Press.

Naoki, K., Gómez, I., López, R., Meneses, R. \& Vargas, J. (2006). Comparación de Modelos de Distribución de Especies para predecir la distribución potencial de vida silvestre en Bolivia. Ecología en Bolivia, 41(1), 65-78.

Oliveira, V.C. \& Sajo, M.G. (2001). Morfo-anatomía caulinar de nove espécies de Orchidaceae. Acta Botanica Brasilica, 15, 177-188.

Pearson, R.G. \& Dawson, T.P. (2003). Predicting the impacts of climate change on the distribution of species: ¿are bioclimate envelope models useful? Global Ecology and Biogeography, 12, 361-371. Doi: 10.1046/j.1466822X.2003.00042.x

Pennington, R. T., Lewis, G. P. \& Ratter, J. A. (2006). An overview of the plant diversity, biogeography and conservation of Neotropical savannas and seasonally dry forests. En: Pennington, R. T., Lewis, G. P. \& Ratter, J. A. (Eds.), Neotropical Savannas and Seasonally Dry Forests (pp.1-30). CRC.

Peñuelas, J., Prieto, P., Beier, C., Cesaraccio, C., de Angelis, P., de Dato, G., Emmett, B. A., Estiarte, M., Garadnai, J., Gorissen, A., Kovács Láng, E., Kröel-Dulay, G., Llorens, L., Pellizzari, G., Riis-Nielsen, T., Schmidt, I.K., Sirca, C., Sowerby, A.,Spano, D. \& Tietema, A. (2007). Response of plant species richness and primary productivity in shrublands along a north-south gradient in Europe to seven years of experimental warming and drought: reductions in primary productivity in the heat and drought year of 2003. Global Change Biology, 13, 2563-2581. Doi: 10.1111/j.1365-2486.2007.01464.x

Pimm, S. L., Jenkins, C. N., Abell, R., Brooks, T. M., Gittleman, J. L., Joppa, L. N., Raven, P. H., Roberts, C. M. \& Sexton, J. O. (2014). The biodiversity of 
species and their rates of extinction, distribution, and protection. Science, 344(6187). Doi: 10.1126/ science.1246752Phillips, S.J. \& Dudík, M. (2008). Modeling of species distributions with MaxEnt: new extensions and a comprehensive evaluation. Ecography, $31,161-175$.

Phillips, S.J., Anderson, R. \& Schapire, R. (2006). Maximum entropy modeling of species geographic distribution. Ecological Modelling, 190, 231-259.

Phillips, R. D., Peakall, R., Hutchinson, M. F., Linde, C. C., Xu, T., Dixon, K. W. \& Hopper, S. D. (2014). Specialized ecological interactions and plant species rarity: the role of pollinators and mycorrhizal fungi across multiple spatial scales. Biological Conservation, 169, 285-295.

Patiño-Uribe, R.D., Rangel-Chacón, O. \& FernandezAlonso, J. L. (2002). Estudio de la vegetación y flora en los montes de María (Colosó, Sucre, Colombia). Libro resúmenes octavo congreso latinoamericano y segundo congreso colombiano de Botánica. Instituto de ciencias naturales, Universidad Nacional de Colombia. 460 p.

Pearce J. \& Ferrier, S. (2000). Evaluating the predictive performance of habitat models developed using logistic regression. Ecological modelling, 133, 225-245.

Pizano, C. \& García, H. (Eds.) (2014). El Bosque seco tropical en Colombia. Bogotá, D.C.: Instituto de investigacion de recursos biológicos Alexander von Humboldt (IAvH). Bogotá, D.C., Colombia. 349 pp.

Primack, R. \& Corlett, R. (2005). Tropical Rain Forest: An Ecological and biogeographical comparison. Blackwell. United Kingdom 336 p.

Ramirez-Villegas, J., Cuesta, F., Devenish, C., Peralvo, M., Jarvis, A. \& Arnillas, C. (2014). Using species distributions models for designing conservation strategies of Tropical Andean biodiversity under climate change. Journal for Nature Conservation, 22(5), 391404.

Reina-Rodriguez, G.A. \& Soriano, I. (2008). Diachronic cartography and spatial pattern assessment in coastal habitats: The case of Torredembarra (northeast Spain). Journal of Coastal Research, 24(1A), 87-98.

Reina-Rodríguez, G.A., Ospina-Calderón, N., Castaño, A., Soriano, I. \& Otero, J. T. (2010). Listado de las orquídeas del Valle del río Cauca y su piedemonte andino (930-1200 m.s.n.m) Sur-occidente colombiano. Cespedesia, 32(90-91), 7-22.

Reina-Rodríguez, G. A., Rubiano, J. E., Castro-Llanos F. A \& Otero, J. T. (2016). Spatial distribution of dry forest orchids in the Cauca river valley and Dagua Canyon: Towards a conservation stategy to climate change. Journal for nature conservation, 30, 32-43.

Reymondin, L., Jarvis, A., Perez-Uribe, A., Touval, J., Argote, K., Rebetez, J., Guevara, E. \& Mulligan, Mark.
(2010). A methodology for near real-time monitoring of habitat change at continental scales using MODISNDVI and TRMM. Remote Sensing of Environment, 21, 983-1008.

Rebêlo, J.M.M. \& Garófalo, C.A. (1997). Comunidades de machos de Euglossini (Hymenoptera: Apidae) em matas semidecíduas do Nordeste do estado de São Paulo. Anais da Sociedade Entomológica do Brasil, 26, 243-255

Riahi, K., Rao, S., Krey, V., Cho, C., Chirkow, V., Fischer, G., Kindermann, G., Nakicenovic, N. \& Rafaj, P. (2011). RCP 8.5 - A Scenario of Comparatively High Greenhouse Gas Emissions. Climatic Change, 109, 33-57.

Richardson, B.A., Richardson, M.J., Scatena, F.N. \& McDowell, W.H., (2000). Effects of nutrient availability and other eleva-tional changes on bromeliad populations and their invertebratecommunities in a humid tropical forest in Puerto Rico. Journal of Tropical Ecology, 16, 167-188.

Roberts, D. L. (2003). Pollination Biology: The role of sexual reproduction in orchid conservation. In: K.W. Dixon, S.P. Kell, R, L, Barrett, P.J. Cribb (Eds.), Orchid Conservation (pp. 113-136). Natural History Publications, Kota Kinabalu.

Roubik, D.W. (1993). Tropical pollinators in the canopy and understory: field data and theory for stratum "preferences". Journal of Insect Behavior, 6, 659-674.

Roubik, D.W. \& Ackerman J.D. (1987). Long-term ecology of euglossine orchid-bees (Apidae: Euglossini) in Panamá. Oecología, 73, 321-333.

RBG Kew (2016). The State of the World's Plants Report 2016. Royal Botanic Gardens, Kew.

Rudas, G.D., Armenteras, S.M. \& Sua-Rodríguez, N. (2002). Indicadores de Seguimiento de la Política de Biodiversidad en la Amazonia Colombiana 2001. Informe Final de Resultados. Proyecto Diseño e Implementación del Sistema de Indicadores de Seguimiento de la Política de Biodiversidad en la Amazonia Colombiana. Instituto Humboldt, CDA, Corpoamazonia, Cormacarena, Instituto Sinchi, Unidad de Parques, Ministerio del Medio Ambiente (Crédito BID 774 OC/CO), Bogotá, Colombia, 105p.

Safont, E., Vegas-Vilarrúbia, T. \& Rull, V. (2012). Use of Environmental Impact Assessment (EIA) tools to set priorities and optimize strategies in biodiversity conservation. Biological conservation, 149, 113-121.

Savage, A. \& Causado, J. (2008). Saguinus oedipus. IUCN 2013. IUCN Red List of Threatened Species. Version 2013.2. <www.iucnredlist.org>.

Sánchez-Azofeifa, G., Quesada, M., Rodríguez, J., Nassar, J., Stoner, K., Castillo, A. \& Garvin, T., Zent, E. L., Calvo-Alvarado, J. C., Kalacska, M.E.R., Fajardo, L., Gamon, J. A. \& Cuevas-Reyes, P. (2005). Research 
priorities for neotropical dry forest. Biotropica, 37 , $477-485$.

Stevens, G. C. (1992). The elevational gradient in altitudinal range: an extensión of Rapoport's latitudinal rule to altitude. American Naturalist, 140, 893-911.

Still, C., Foster, P. N. \& Schneider, S. H. (1999). Simulating the effects of climate change on tropical montane cloud forests. Nature, 398, 608-610.

Sandino, J.C. (2004). Are there any agricultural effects on the capture rates of male euglossine bees (Apidae: Euglossini). Revista de Biología Tropical, 52(1), 115118.

Thomas, C. D., Cameron, A., Green, R. E., Bakkenes, M., Beaumont, L. J., Collingham, Y. C., Erasmus, B.F.N., de Sequeria, M. F., Grainger, A., Hannah, L., Hughes, L.,Huntley, B., van Jaarsveld, A. S., Midgley, G. F., Miles, L., Ortega-Huerta, M. A., Peterson, A. T., Phillips, O. L. \& Williams, S.E. (2004). Extinction risk from climate change. Nature, 427, 145-148.

Thuiller, W. (2004). Patterns and uncertainties of species' range shifts under climate change. Global Change Biology, 10, 2020-2027.

Thuiller, W., Albert, C., Araujo, M.B., Berry, P.M., Cabeza, M., Guisan, A., Hickler, T., Midgley, G.F., Paterson, J., Schurr, F.M., Sykes, M.T. \& Zimmermann, N.E. (2008). Predicting global change impacts on plant species' distributions: future challenges. Perspectives in Plant Ecology, Evolution and Systematics, 9, 137-152.

Torres, E. F., Fermín, F.R. \& Yelitza, L. (2007). Estudio morfo-anatómico de dos orquídeas de una selva nublada tropical. Interciencia, 32(6), 410-418.

Uehara-Prado, M. \& Garófalo, C.A. (2006). Small-scale elevational variation in the abundance of Eufriesea violacea (Blanchard) (Hymenoptera: Apidae). Neotropical Entomology, 35(4), 446-451.

Urban, M.C. (2015). Acelerating extinction risk from climate change. Science, 348(6234), 571-573.

Van der Hamen, T., Werner, J. \& van Dommelen, H. (1973). Palynological record of the upheaval of the northern Andes: a study of the pliocene and lower Quaternary of the Colombia eastern cordillera and the early evolution of its high-andean biota. Review of paleobotany and palynology, 16, 1-122.

Van der Wal, J., Shoo, L. P., Graham, C. \& Williams, S.E. (2009). Selecting pseudo-absence data for presenceonly distribution modeling: How far should you stray from what you know? Ecological Modelling, 220, 589594.

Vélez, M. I., Berrío, J. C., Hooghiemstra, H. \& Metcalfe, S. (2005). Palaeoenvironmental changes during the last ca. 8529 cal yr in the dry forest ecosystem of the Patía Valley. Palaeogeography, Palaeoclimatology, Palaeoecology, 216, 279-302.
Viera, A.J. \& Garrett, J.M. (2005). Understanding interobserver agreement: The kappa statistic. Family medicine, 37(5), 360-363. Warren, D. \& Seifert, S. (2011). Ecological niche modelling in MaxEnt: The importance of model complexity and the performance of model selection criteria. Ecological applications, 21 (2), 335-342.

Whitten, W.M., Young, A.M. \& Stern, D.L. (1993). Nonfloral sources of chemicals that attract male euglossine bees. Journal of Chemical Ecology, 19, 3017-3027.

Wiens, J. A., Stralberg, D., Jongsomjita, D., Howell, C. A. \& Snyder, M. A. (2009). Niches, models, and climate change: Assessing the assumptions and uncertainties. Proceedings of the National Academy of Sciences, 106, 19729-19736.

Williams, N.H. (1982). The biology of orchids and euglossine bees. In: J. Arditti (Ed.), Orchid biology II (pp.121-169). Cornell University Press, Ithaca, New York.

Wiz, M.S., Hijmans, R.J., Li, J., Peterson, A.T., Graham, C.H., Guisan, A. \& NCEAS Predicting Species Distributions Working Group. (2008). Efects of samples size on the performance of species distribution models. Diversity and distributions, 14, 763-773.

Wieczorek, J., Bloom, D., Guralnick, R., Blum, S., Döring, M., Giovanni, R., Robertson, T. \& Vieglais, D. (2012). Darwin Core: An Evolving Community-Developed Biodiversity Data Standard. Plos one 7(1). doi: 10.1371/ journal.pone.0029715

Young, K.R. \& Lipton, J. (2006). Adaptive governance and climate change in the tropical highlands of western south america. Climatic change, 78, 63-102.

WEB SITES FOR DATA USED IN THIS RESEARCH

Biological Information Catalogue CEIBA-IAvH. I2DInstitutional data infrastructure. Retrieved at: http:// i2d.humboldt.org.co/ceiba/; http://i2d.humboldt.org.co/ ceiba/resource.do?r=rrbb_bst_orquideas_2015; http:// i2d.humboldt.org.co/ceiba/resource.do? $\mathrm{r}=\mathrm{rrbb}$ _bst orquideas_observaciones_2015; http://i2d.humboldt. org.co/ceiba/resource.do?r=rbb_bst_orquideas identificaciones_2015

Geodata Portal of King's College London. Retrieved at: http:/www.policysupport.org/waterworld

Insect collection of the Entomological Museum of the Universidad del Valle MUSENUV (2013). Retrieved at: http://ipt.sibcolombia.net/valle/resource.do?r=insectosuniversidad-del-valle. I-Terra. Retrieved at:http:/www. terra-i.org/terra-i.html

Joint Research Centre. Retrieved at: http://bioval.jrc. ec.europa.eu/products/gam/index.html

Worldclim Graham \& Hijmans, 2006. Retrieved at: http:// www.worldclim.org

LANKESTERIANA 17(1). 2017. (C) Universidad de Costa Rica, 2017. 


\section{APPENDICES}

APPENDIX 1. Species of orchids selected for modelling, their distribution in departments in Colombia, altitudes and notes on their ecology.

\begin{tabular}{l|l|l}
\hline Species & \multicolumn{1}{|c|}{ Distribution } & Supplemental notes \\
\hline & Neotropical; (Bol, Col, CR, Ecu, & $\begin{array}{l}\text { Rounded and succulent leaves to store water and prevent dessication. } \\
\text { Grows in open areas exposed to light. Grows in dry forests and sub- } \\
\text { Brassavola nodosa } \\
\text { (L.) Lindl. }\end{array}$ \\
$\begin{array}{ll}\text { Guy, Mex, Per) Col: (Ant, San, Bol, } \\
\text { Cal, Ces, Cor, Cho, Cun, Gua, } \\
\text { Mag, San, Suc, Tol) 5-950 m. }\end{array}$ & $\begin{array}{l}\text { tortuosa, Pereskia guamacho, Samanea saman, Crescentia cujete and } \\
\text { Anacardium excelsum. }\end{array}$ \\
\hline
\end{tabular}

Equipped with pseudobulbs up to $25 \mathrm{~cm}$ in length to store water. Prefers perimeter areas of dry forest and riverine forests with medium

\begin{tabular}{l|l}
$\begin{array}{l}\text { Catasetum tabulare } \\
\text { Lindl. }\end{array}$ & $\begin{array}{l}\text { Endemic; (Col) 200-1350 m. Col: } \\
\text { (Ant, Ris, VdC, Tol, Suc) }\end{array}$
\end{tabular}
brightness. It has been observed in living fences and at the perimeters of abandoned coffee plantations, as well as in groups of trees outside the forest but sheltered from the wind. It grows on Gliricidia sepium, Senna spectabilis, Anacardium excelsum, Machaerium capote and Brosimum alicastrum.

Equipped with pseudobulbs up to $60 \mathrm{~cm}$ in length to store water. Grows in dry forest and sub-xerophytic dry shrubland and as a terrestrial plant in outcrops of sedimentary rocks in foothill areas with frequent wildfire, despite which this species persists. As an epiphyte, it has been observed on Anacardium excelsum, Sterculia apetala and Elaeis guineensis.

Possesses elongated pseudobulbs up to $40 \mathrm{~cm}$ in length. It grows in lowlands and Andean foothills and is present in dry forests, subxerophytic shrubland and seasonally flooded forests, including wooded pasture. Populations present in the Cauca River Valley occupy the altitudinal ceiling of the continent. It has been observed on Anacardium excelsum, Erythroxylum ulei, Ficus insipida, Xylopia ligustrifolia, Laetia americana and Oreopanax cecropifolius.

Has waxy cuticle as an adaptation to the conditions of water stress. Grows in dry forest, seasonally flooded forests, riverine forests and forest-pasture perimeters in areas of high and medium brightness. It has been observed on Anacardium excelsum, Laetia americana, Luehea seemannii, Guarea guidonia, Erythroxylum ulei, Guarea kunthiana, Chlorophora tinctoria and Ficus obtusifolia.

Small epiphyte with rounded leaves and thick cuticle. Grows in riparian forests, sub-xerophytic shrubland and seasonally flooded forests. Establishes both on the exterior branches of shrubs a few metres from the ground and in treetops more than 30 metres high. It has been observed on Ficus insipida, Lonchocarpus sp., Anacardium excelsum, Neea divaricata, Clusia minor, Zanthoxylum fagara and Clusia fructiangusta.

Only terrestrial species, occasional epiphyte. Possesses underground succulent pseudobulbs for water storage. Extensive global distribution occurring in both the Paleotropics and Neotropics. Grows in dry forests dominated by Anacardium excelsum, Sabal mauritiiformis, Syagrus sancona and Attalea butyracea in transition areas between pasture and riparian forest. This adaptation to different ombro climates has enabled its colonization to different environments around the world.

Possesses small oval pseudobulbs to store water. Grows at perimeters of riverine forests and seasonally flooded forests. More abundant below $500 \mathrm{~m}$. It has been observed on Laetia americana, Guarea guidonia, Vitex orinocensis, Inga spectabilis and Miconia sp. 
APPENDIX 1 (continues).

\begin{tabular}{|c|c|c|}
\hline Species & Distribution & Supplemental notes \\
\hline $\begin{array}{l}\text { Scaphyglottis prolifera } \\
\text { (R. Br.) Cogn. }\end{array}$ & $\begin{array}{l}\text { Neotropical; (Bel, Bol, Col, CR, } \\
\text { Ecu, Gua, Guy, Hnd, Jam, Mex, } \\
\text { Nic, Pan, Per, Tri, Ven). Col: (Ant, } \\
\text { Cau, Cho, Cun, Gua, Hui, Mag, } \\
\text { Met, Ris, San, VdC) 500-1600 m. }\end{array}$ & $\begin{array}{l}\text { Possesses multiple elongated and plump pseudobulbs to prevent } \\
\text { dessication. Grows in riparian forests, sub-xerophytic shrubland and } \\
\text { forest perimeters or at the interior of forests with neighbouring areas of } \\
\text { pasture. In localities with semi-arid climate, this plant finds refuge in the } \\
\text { depressions of water channels where the microclimate is more humid. } \\
\text { It has been observed on Brosimum alicastrum, Matisia sp., Guarea } \\
\text { guidonia, Anacardium excelsum, Guazuma ulmifolia, Amyris pinnata, } \\
\text { Daphnopsis americana, Aegiphila grandis, Machaerium capote, Guarea } \\
\text { guidonia, Hura crepitans, Erythroxylum ulei, Luehea seemannii, Laetia } \\
\text { americana and Dendropanax colombianum. }\end{array}$ \\
\hline $\begin{array}{l}\text { Trichocentrum } \\
\text { carthagenense (Jacq.) } \\
\text { M.W. Chase \& N.H. } \\
\text { Williams }\end{array}$ & $\begin{array}{l}\text { Neotropical; (Bel, Col, CR., Gua, } \\
\text { Hnd, Mex, Nic, Pan, Sal, Ven.) } \\
\text { Col: (Ant, Ara, Bol, Boy, Cas, Cau, } \\
\text { Cor, Cun, Gua, Hui, Mag, Met, } \\
\text { Boy, Tol, Mag, San, Suc, VdC, Vic) } \\
\text { 50-1200 m. }\end{array}$ & $\begin{array}{l}\text { Waxy cuticle for adaptation to conditions of water stress. Grows in } \\
\text { dry forest and in flooded and non-flooded habitats, sub-xerophytic } \\
\text { shrubland, and riverine forests. Frequently epiphytic on trunks and } \\
\text { stems a few metres from the ground and less often in matts of leaf } \\
\text { litter and decaying trunks. It has been observed on Eugenia bicolor, } \\
\text { Anacardium excelsum, Citharexylum kunthianum, Eugenia monticola, } \\
\text { Neea divaricata, Ardisia guianensis, Guazuma ulmifolia, Calliandra sp., } \\
\text { Jacaranda obtusifolia, Maclura tinctoria and Machaerium capote. }\end{array}$ \\
\hline $\begin{array}{l}\text { Trizeuxis falcata } \\
\text { Lindl. }\end{array}$ & $\begin{array}{l}\text { Neotropical; (Bol, Bra, Col, CR, } \\
\text { Ecu, Pan, Per, Ven). Col (Ant, Ara, } \\
\text { Boy, Caq, Cas, Cau, Cun, Met, } \\
\text { Mag, VdC, Qui, Ris, San) 100- } \\
1500 \text { m. }\end{array}$ & $\begin{array}{l}\text { Small pseudobulbs and flattened leaves reduce the effect of the wind } \\
\text { to minimise dessication. Frequent on fences, trunks, roadsides, and } \\
\text { citrus trees and always found in environments of bright light and with } \\
\text { a high level of recruitment. Rarely found at the interior of the forest. It } \\
\text { has been observed on Psidium guajava, Citrus spp., Crescentia cujete, } \\
\text { Parathesis reticulata, Coffea arabica, Guapira costaricana and Eugenia } \\
\text { sp. }\end{array}$ \\
\hline $\begin{array}{l}\text { Vanilla calyculata } \\
\text { Schltr. }\end{array}$ & $\begin{array}{l}\text { Neotropical; (Col, Hnd, Mex, Sal) } \\
\text { Col: (Hui, Mag, Nar, Tol, VdC) } 570 \\
-1200 \text { m. }\end{array}$ & $\begin{array}{l}\text { Possesses creeping habit and swollen stalks with greater capacity to } \\
\text { store water and prevent desiccation. Grows in foothills of the Central } \\
\text { Cordillera and Western Cordillera in dry and sub-xerophytic habitats, } \\
\text { as well as in alluvial deposits of the inter-Andean valleys. It has been } \\
\text { observed on Cupania americana, Eugenia monticola and Psidium } \\
\text { sartorianum. }\end{array}$ \\
\hline
\end{tabular}

Country abbreviations: Arg: Argentina; Bel: Belize; Bhm: Bahamas; Bol: Bolivia; Bra: Brasil; CR: Costa Rica; Col: Colombia; Cub: Cuba; Ecu: Ecuador; Gua: Guatemala; Guy: Guyana; GFr: French Guyana; Hat: Haiti; Hnd: Honduras; Jam: Jamaica; Mex: Mexico; Nic: Nicaragua; Pan: Panama; Per: Peru; RD: Dominican Republic; Sal: El Salvador; Sur: Surinam; T\&T: Trinidad\& Tobago; Urg: Uruguay; PR: Puerto Rico; Par: Paraguay; Ven: Venezuela. Abbreviations of departments of Colombia: Ama: Amazonas; Ant: Antioquia; Ara: Arauca; Atl: Atlantic; Bol: Bolívar; Boy: Boyacá Cal: Caldas; Caq: Caquetá; Cau: Cauca; Cas: Casanare; Ces: Cesar; Cho: Chocó; Cor: Córdoba; Cun: Cundinamarca; Guai: Guainía; Guav: Guaviare; Guaj: La Guajira; Hui: Huila; Mag: Magdalena; Met: Meta; Nar: Nariño; Nsa: North of Santander; Put: Putumayo; Qui: Quindío; Ris: Risaralda; San: Santander; Sap: Sán Andrés and Providencia; Suc: Sucre; Tol: Tolima; VdC: Valle del Cauca; Vau: Vaupés; Vich: Vichada.

ApPENDix 2. Kappa value according to Monserud and Leemans (1992).

\begin{tabular}{l|c}
\hline Kappa Value & Estimation \\
\hline $\mathrm{K}<0.05$ & No agreement \\
\hline $0.05 \leq \mathrm{K}<0.20$ & Very poor \\
\hline $0.20 \leq \mathrm{K}<0.40$ & Poor \\
\hline $0.40 \leq \mathrm{K}<0.55$ & Medium \\
\hline $0.55 \leq \mathrm{K}<0.70$ & Good \\
\hline $0.70 \leq \mathrm{K}<0.85$ & Very good \\
\hline $0.85 \leq \mathrm{K}<0.99$ & Excellent \\
\hline $0.99 \leq \mathrm{K} \leq 100$ & Perfect \\
\hline
\end{tabular}


APPENDIX 3. Variance Analysis of one factor.

\begin{tabular}{|c|c|c|c|c|c|c|}
\hline \multicolumn{5}{|l|}{ Summary } & & \\
\hline Groups & Count & Sum & Mean & Variance & & \\
\hline Presente & 10213 & 10041305 & 983,1885832 & 54291,62268 & & \\
\hline $2030 a$ & 3429 & 3996036 & 1165,364829 & 49544,98559 & & \\
\hline $2050 b$ & 2237 & 3051427 & 1364,071077 & 38030,01239 & & \\
\hline \multicolumn{7}{|l|}{ Variance Analysis } \\
\hline Origin of variations & Sum of squares & $\begin{array}{l}\text { Degrees } \\
\text { of freedom }\end{array}$ & $\begin{array}{c}\text { Average of } \\
\text { squares }\end{array}$ & $F$ & $P$ Value Probability & Critical value for $F$ \\
\hline Between groups & 300995377,6 & 2 & 150497688,8 & 2952,301082 & 0,0000 & 2,996297626 \\
\hline Within groups & 809301369,1 & 15876 & 50976,40269 & & & \\
\hline Total & 1110296747 & 15878 & & & & \\
\hline
\end{tabular}




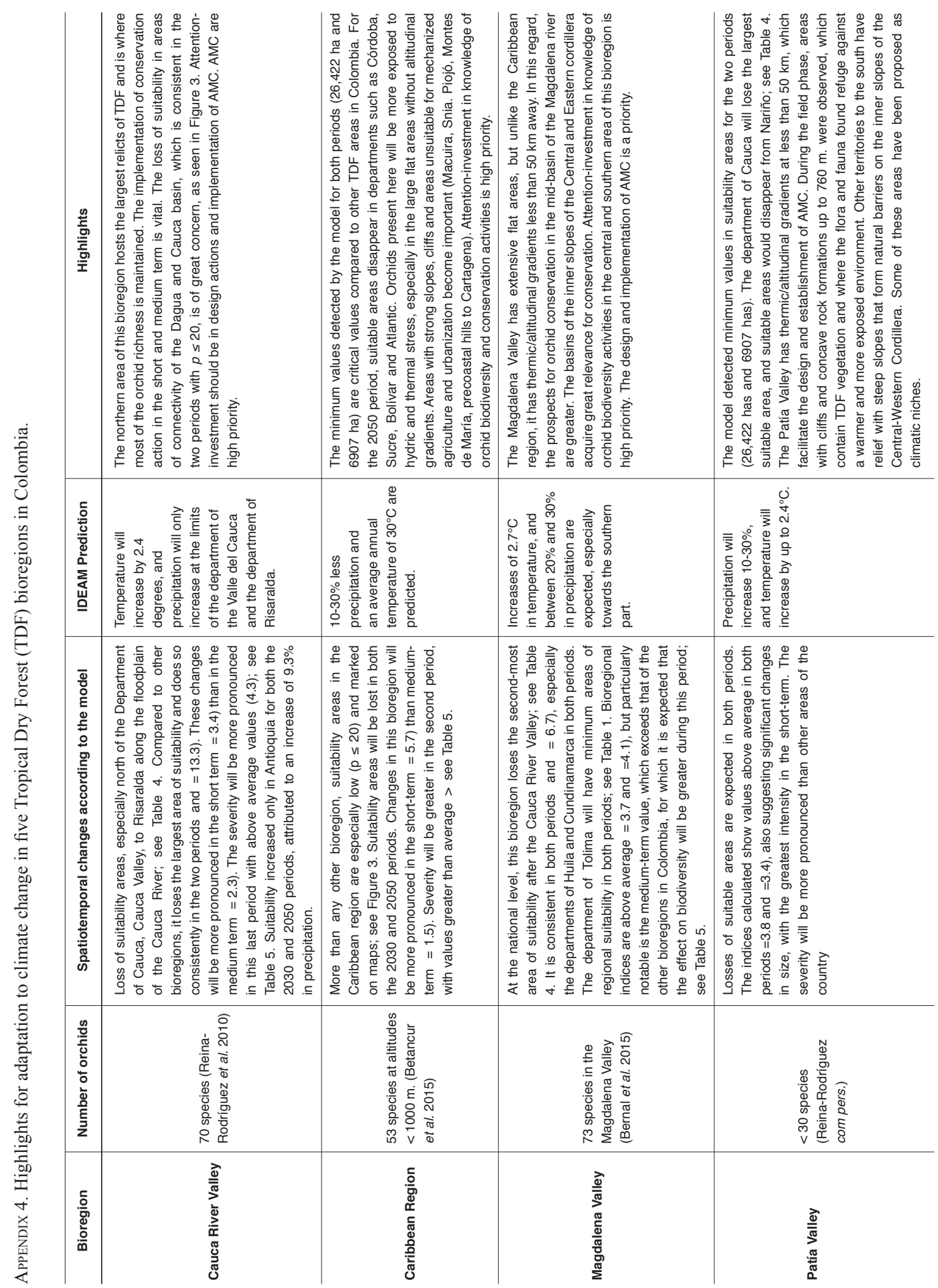




\begin{tabular}{|c|c|c|c|c|c|c|c|c|c|c|c|c|c|c|}
\hline \multirow{5}{*}{$\begin{array}{l}\frac{0}{2} \\
\frac{5}{5} \\
\frac{5}{I} \\
\frac{9}{I}\end{array}$} & \multirow{5}{*}{ 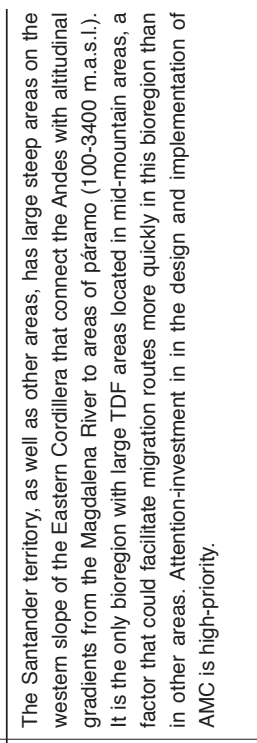 } & \multirow{13}{*}{ 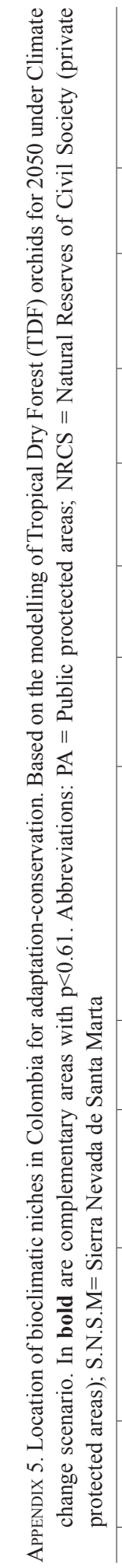 } & 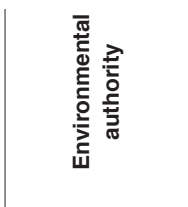 & $\begin{array}{l}0 \\
0 \\
0 \\
0 \\
0 \\
0\end{array}$ & O & Ò & Oे & O) & O্ & O & 芳 & 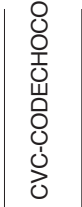 & $\begin{array}{l}0 \\
0\end{array}$ & d \\
\hline & & & 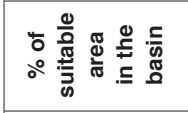 & $\stackrel{\text { S }}{\text { N }}$ & 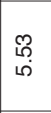 & & 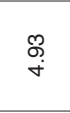 & $\begin{array}{l}\tilde{\sigma} \\
\dot{\omega} \\
\omega\end{array}$ & 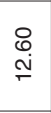 & $\hat{\circ}$ & $\begin{array}{l}0 \\
0 \\
0\end{array}$ & $\stackrel{\text { N̦ }}{\text { N }}$ & 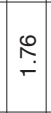 & 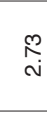 \\
\hline & & & 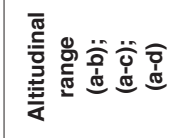 & $\begin{array}{l}\bar{o} \\
\bar{o} \\
\bar{o} \\
q\end{array}$ & 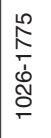 & 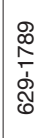 & $\begin{array}{l}\stackrel{\stackrel{\infty}{N}}{\frac{1}{1}} \\
\stackrel{N}{0}\end{array}$ & 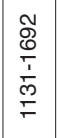 & $\begin{array}{l}\frac{0}{0} \\
\frac{0}{1} \\
\dot{y} \\
\frac{1}{6}\end{array}$ & 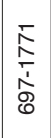 & 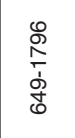 & 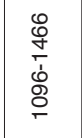 & $\begin{array}{c}\mathfrak{N} \\
\stackrel{N}{ } \\
\bar{\alpha} \\
\dot{\alpha} \\
\sigma \\
\sigma\end{array}$ & 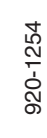 \\
\hline & & & 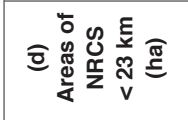 & $\widetilde{\infty}$ & & & & & $\underset{\sigma}{\sigma}$ & & 胥 & $\stackrel{\infty}{\stackrel{2}{N}}$ & & \\
\hline & & & 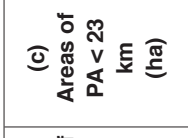 & $\begin{array}{l}\infty \\
\stackrel{0}{0} \\
\stackrel{0}{0}\end{array}$ & & 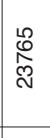 & & $\overline{\text { ลิ }}$ & & 离 & 望 & & $\begin{array}{l}0 \\
0\end{array}$ & \\
\hline 訔 & 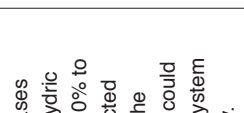 & & 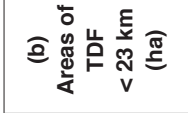 & $\begin{array}{l}\infty \\
\infty \\
\stackrel{N}{N} \\
\end{array}$ & & & 尺̊ & & $\stackrel{\stackrel{\rho}{\rightleftharpoons}}{\circ}$ & & $\frac{R}{n}$ & $\hat{\sigma}$ & $\bar{\gamma}$ & ֻ \\
\hline 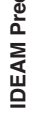 & 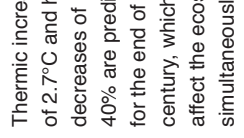 & & 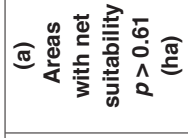 & 苍 & $\stackrel{\infty}{\stackrel{\infty}{\%}}$ & & $\begin{array}{l}\infty \\
\stackrel{\infty}{\infty}\end{array}$ & & 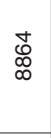 & & స్త్ర & 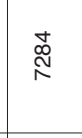 & $\begin{array}{l}\hat{0} \\
\stackrel{\rho}{n} \\
\sim\end{array}$ & $\stackrel{\text { S }}{\mathrm{N}}$ \\
\hline 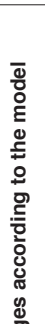 & 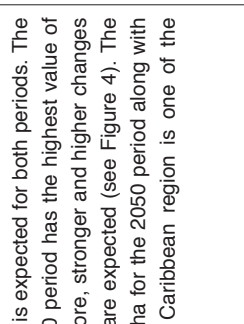 & & 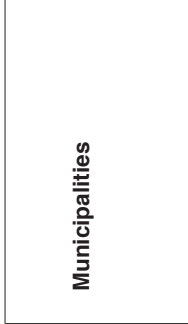 & 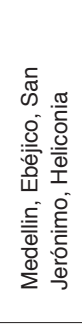 & 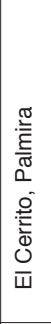 & 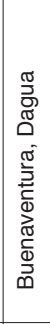 & 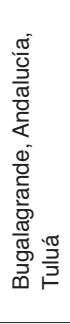 & 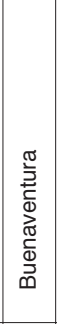 & 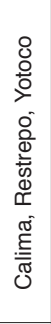 & 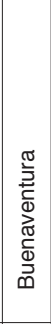 & 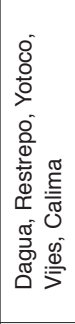 & 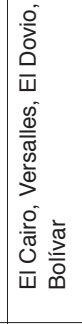 & 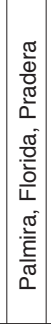 & 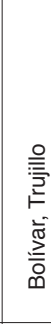 \\
\hline$\frac{\frac{5}{\pi}}{\frac{5}{0}}$ & 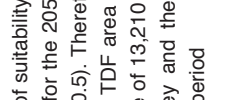 & & $\frac{\%}{\omega}$ & 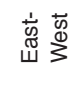 & 萬 & 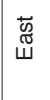 & $\stackrel{D}{D}^{\bar{D}}$ & 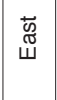 & $\begin{array}{l}\text { 若 } \\
\text { w }\end{array}$ & \begin{tabular}{|l} 
\\
$\tilde{B}$ \\
$\tilde{W}$
\end{tabular} & $\begin{array}{l}\text { 若 } \\
\text { W }\end{array}$ & $\begin{array}{l}\text { 芯 } \\
\text { W }\end{array}$ & 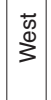 & $\begin{array}{c}\text { 若 } \\
\text { ய }\end{array}$ \\
\hline 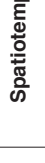 & 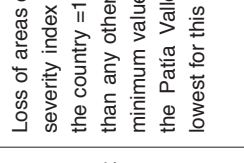 & & 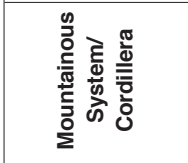 & 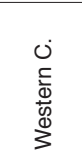 & $\begin{array}{l}\dot{0} \\
\frac{\pi}{\pi} \\
\frac{\pi}{0} \\
0 \\
0\end{array}$ & 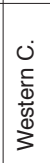 & 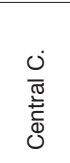 & 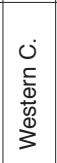 & 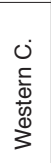 & 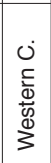 & 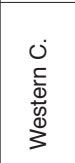 & 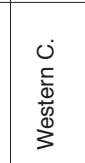 & 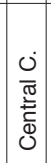 & 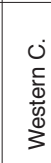 \\
\hline 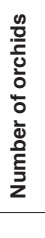 & 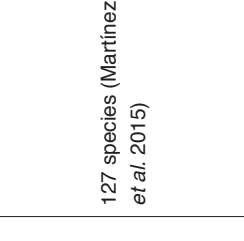 & & 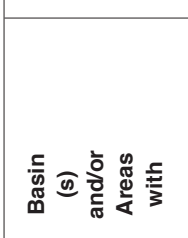 & 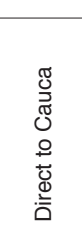 & 莺 & 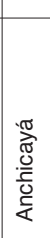 & 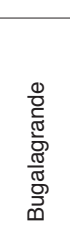 & 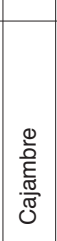 & $\frac{\widetilde{\sigma}}{\underline{\underline{E}}}$ & 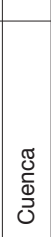 & $\begin{array}{l}\frac{\pi}{3} \\
\stackrel{\pi}{0} \\
0\end{array}$ & 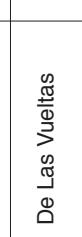 & 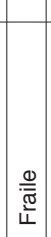 & 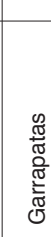 \\
\hline 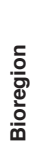 & 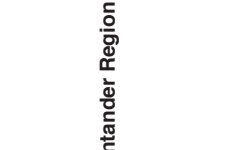 & & 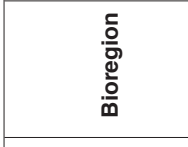 & & & & & & & & & & & \\
\hline & & & $\underline{\underline{0}}$ & - & $\sim$ & $m$ & $\nabla$ & \llcorner & 0 & $\wedge$ & $\infty$ & $\infty$ & & \\
\hline
\end{tabular}




\begin{tabular}{|c|c|c|c|c|c|c|c|c|c|c|c|c|c|c|c|c|c|c|c|c|c|}
\hline $\begin{array}{l}0 \\
0 \\
0 \\
0 \\
0 \\
0\end{array}$ & O & 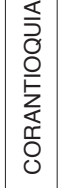 & O্ & O & $\begin{array}{l}0 \\
0 \\
\sum_{0}^{1} \\
0 \\
\frac{1}{0} \\
0 \\
0\end{array}$ & 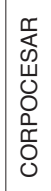 & $\begin{array}{l}\frac{1}{0} \\
0 \\
0 \\
0 \\
0 \\
0 \\
0 \\
0\end{array}$ & 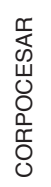 & 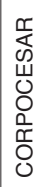 & 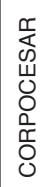 & 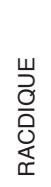 & 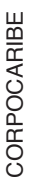 & 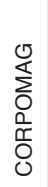 & 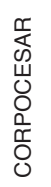 & 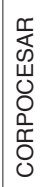 & 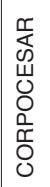 & 祃 & $\begin{array}{l}\frac{山}{\partial} \\
\frac{0}{0} \\
\frac{\alpha}{d}\end{array}$ & 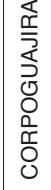 & 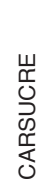 & 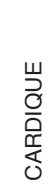 \\
\hline & 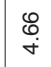 & $\hat{o}$ & 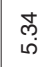 & ஜ̊ & ָָ & $\stackrel{\hat{N}}{0}$ & 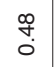 & $\hat{o}$ & 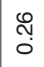 & & $\stackrel{1}{\circ}$ & $\stackrel{l}{\circ}$ & & & $\frac{\rho}{\rho}$ & & & & & & \\
\hline
\end{tabular}

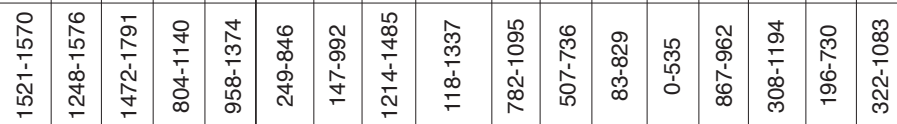

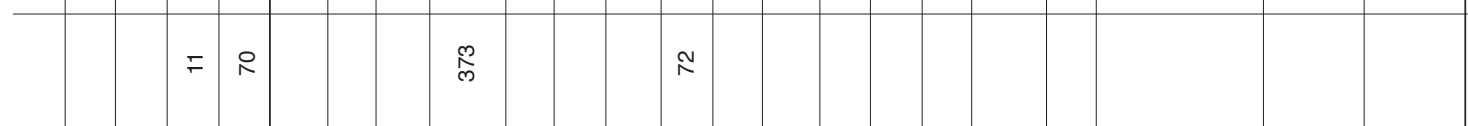

옹

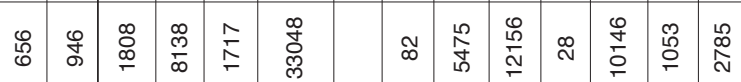

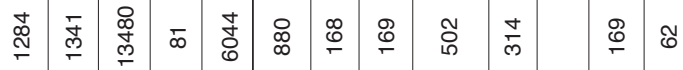

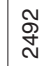

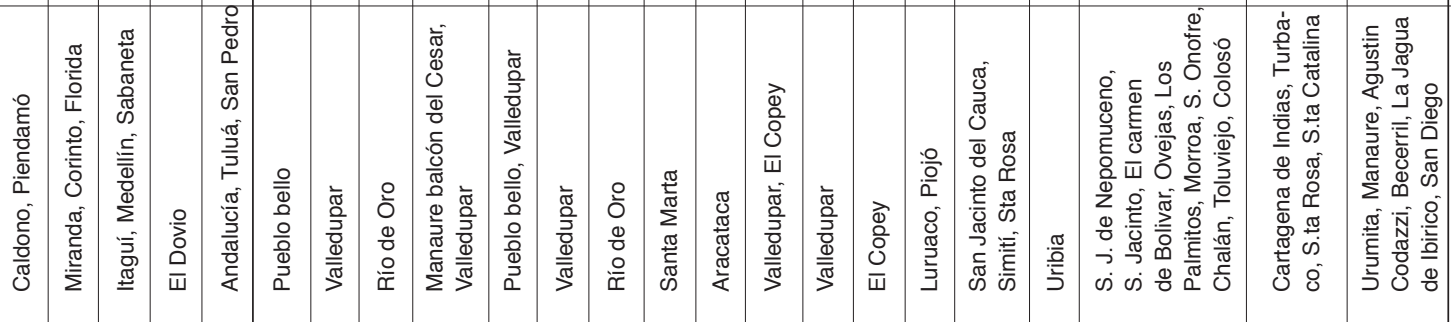

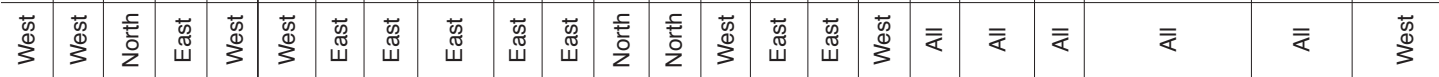

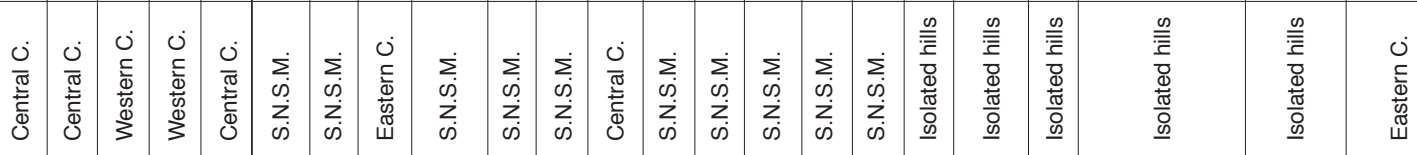

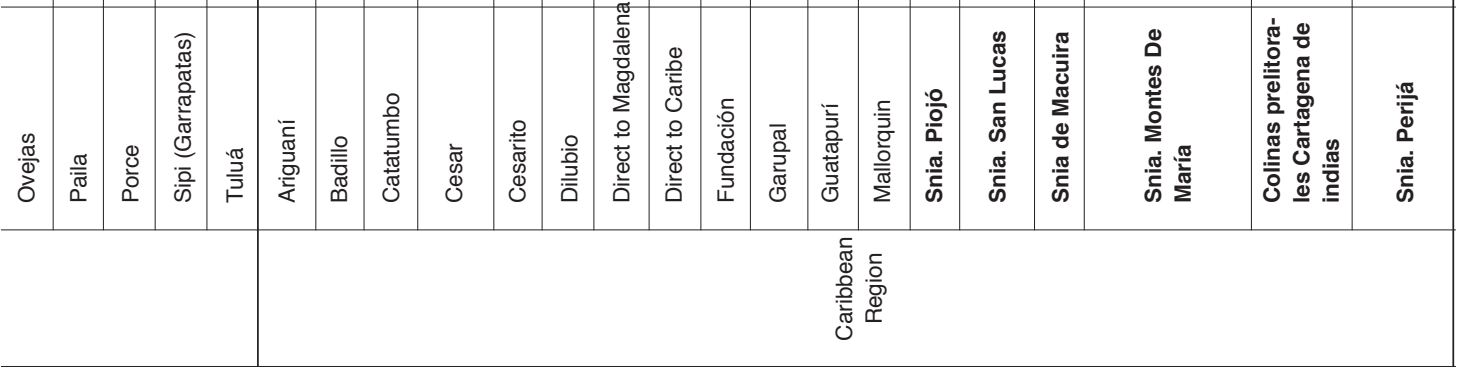

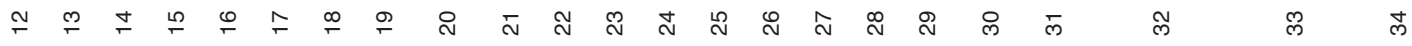




\begin{tabular}{|c|c|c|c|c|c|c|c|c|c|c|c|c|c|c|c|c|c|c|c|}
\hline 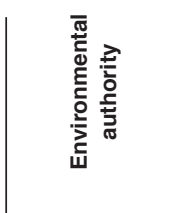 & $\sum_{0}$ & 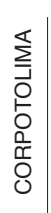 & 孚 & $\sum_{0}$ & 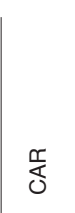 & $\sum_{0}$ & 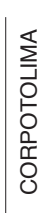 & 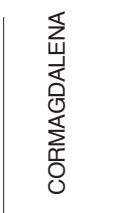 & $\sum_{0}$ & 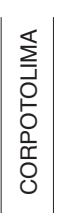 & 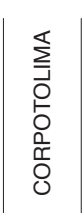 & $\sum_{0}$ & 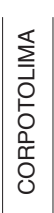 & 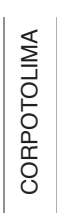 & $\frac{\pi}{\delta}$ & $\frac{\pi}{\overleftarrow{c}}$ & 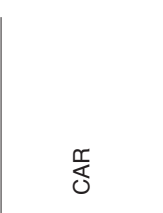 & $\sum_{0}$ & $\sum_{0}$ \\
\hline 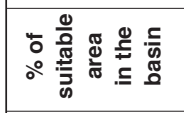 & $\begin{array}{l}0 \\
0\end{array}$ & & 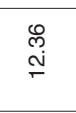 & $\begin{array}{l}\stackrel{0}{0} \\
\infty\end{array}$ & চீ. & $\stackrel{\substack{0 \\
0}}{0}$ & $\stackrel{\text { L̊ }}{\circ}$ & $\hat{0}$ & $\begin{array}{l}0 \\
0 \\
0\end{array}$ & & $\underset{\stackrel{N}{\Gamma}}{\stackrel{N}{\Gamma}}$ & $\stackrel{\infty}{\stackrel{\infty}{0}}$ & & & $\stackrel{\leftrightarrow}{\stackrel{\leftrightarrow}{\circ}}$ & $\stackrel{\widehat{N}}{\text { iv }}$ & $\begin{array}{l}\stackrel{\infty}{+} \\
\stackrel{m}{\sim}\end{array}$ & $\stackrel{\infty}{\circ}$ & $\stackrel{\text { L̊ }}{0}$ \\
\hline 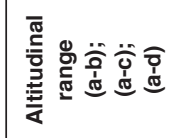 & $\begin{array}{l}0 \\
\stackrel{1}{1} \\
\stackrel{\hat{N}}{R}\end{array}$ & \begin{tabular}{l}
$\hat{n}$ \\
$\hat{n}$ \\
\multirow{N}{N}{} \\
\end{tabular} & $\begin{array}{l}\frac{\infty}{0} \\
\frac{1}{0} \\
\frac{1}{\infty} \\
\frac{1}{b}\end{array}$ & 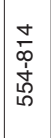 & 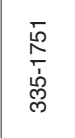 & 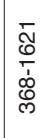 & $\begin{array}{l}\infty \\
0 \\
\\
\dot{1} \\
0 \\
0\end{array}$ & 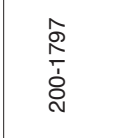 & 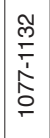 & $\begin{array}{l}8 \\
0 \\
0 \\
0 \\
0 \\
0\end{array}$ & $\begin{array}{l}\hat{\stackrel{N}{ }} \\
\stackrel{\infty}{0} \\
\stackrel{\sigma}{\sigma}\end{array}$ & $\begin{array}{l}\stackrel{\circ}{0} \\
\stackrel{0}{\circ} \\
\dot{\phi} \\
\dot{\sigma}\end{array}$ & 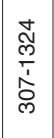 & $\begin{array}{l}\hat{p} \\
\hat{N} \\
\hat{N} \\
\text { N }\end{array}$ & $\begin{array}{l}\infty \\
\stackrel{\infty}{N} \\
\sim \\
\infty \\
\infty \\
e\end{array}$ & 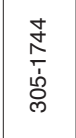 & $\begin{array}{l}\stackrel{8}{ } \\
\stackrel{1}{0} \\
\dot{0} \\
\varnothing\end{array}$ & 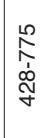 & 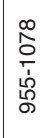 \\
\hline 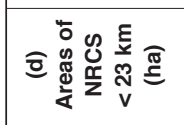 & & & & & & & & & & & 으 & & & & & - & $\sim$ & & \\
\hline 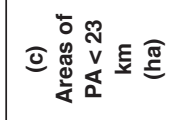 & & & & & ్ָల & 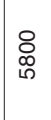 & 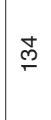 & 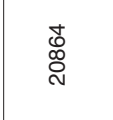 & & & 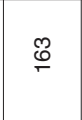 & & $\hat{\infty}$ & & & 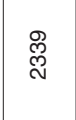 & & $\begin{array}{l}: \\
\stackrel{\circ}{\circ}\end{array}$ & \\
\hline 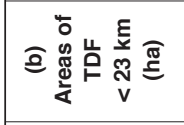 & ஸั & $\widetilde{N}$ & 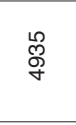 & 음 & $\underset{\infty}{\mathscr{N}}$ & 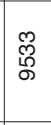 & $\stackrel{\infty}{\sim}$ & 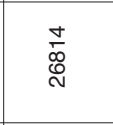 & & م & 员 & $\begin{array}{l}\infty \\
\text { o } \\
\text { b }\end{array}$ & 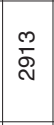 & 8 & 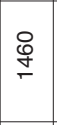 & ્ָల & & & \\
\hline 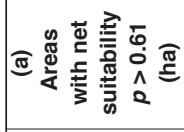 & $\stackrel{n}{\stackrel{\rho}{\sim}}$ & & $\begin{array}{l}\stackrel{2}{0} \\
\stackrel{0}{0}\end{array}$ & 尃 & 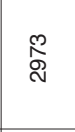 & $\stackrel{N}{\stackrel{N}{F}}$ & $\mathscr{\infty}$ & 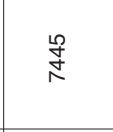 & 守 & & $\begin{array}{l}\stackrel{R}{0} \\
\text { in }\end{array}$ & ஜ & & & $\stackrel{\text { }}{\stackrel{\sim}{\sim}}$ & 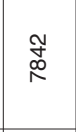 & $\stackrel{\stackrel{N}{L}}{\frac{L}{\Gamma}}$ & $\stackrel{\leftrightarrow}{\circ}$ & ळ \\
\hline 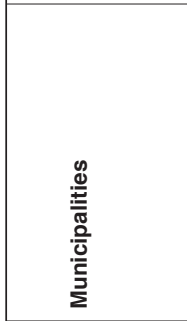 & $\stackrel{\frac{\pi}{\pi}}{\frac{\pi}{2}}$ & 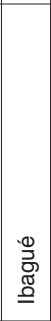 & 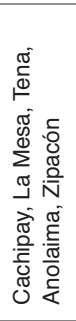 & 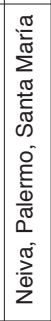 & 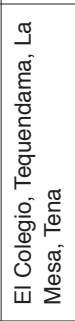 & \begin{tabular}{|l}
$\frac{\pi}{2}$ \\
$\frac{\pi}{4}$ \\
$\frac{3}{3}$ \\
$\frac{0}{4}$
\end{tabular} & 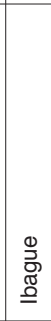 & 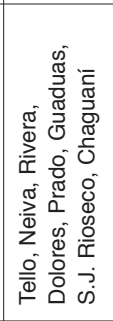 & 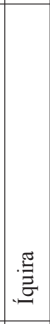 & 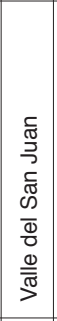 & 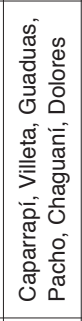 & 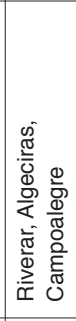 & 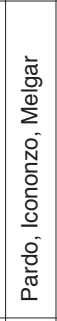 & 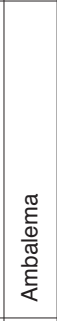 & 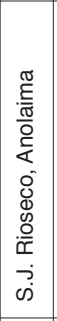 & 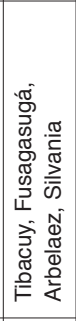 & 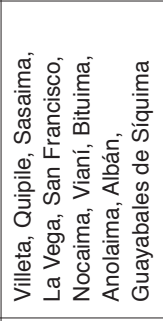 & 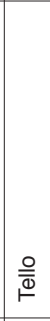 & 誉 \\
\hline$\frac{\AA}{\circ}$ & $\begin{array}{l}\text { 芯 } \\
\text { Wु }\end{array}$ & 急 & $\begin{array}{l}\vec{\Phi} \\
\stackrel{\Delta}{3}^{3}\end{array}$ & \begin{tabular}{|l} 
范 \\
热
\end{tabular} & $\begin{array}{l}\overline{\mathscr{D}} \\
\stackrel{M}{3}^{2}\end{array}$ & $\begin{array}{l}\overline{\mathscr{D}} \\
\sum^{\mathbb{N}}\end{array}$ & \begin{tabular}{|l} 
芯 \\
ய
\end{tabular} & 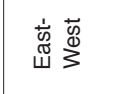 & \begin{tabular}{|l} 
\\
梕 \\
|
\end{tabular} & 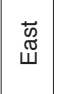 & $\begin{array}{l}\vec{\Phi} \\
\sum_{3}^{\infty}\end{array}$ & $\begin{array}{l}\vec{\Phi} \\
\stackrel{M}{3}^{3}\end{array}$ & $\begin{array}{l}\bar{\Phi} \\
3^{\circ}\end{array}$ & 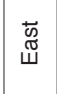 & 芯 & 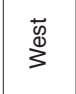 & 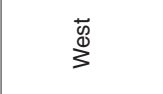 & $\begin{array}{l}\bar{\Phi} \\
\sum_{3}^{\circ}\end{array}$ & 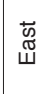 \\
\hline 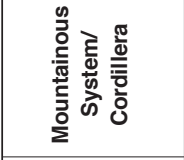 & 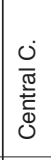 & 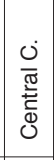 & 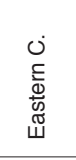 & 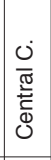 & 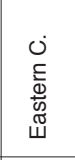 & 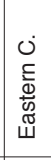 & 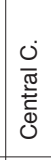 & 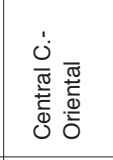 & 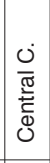 & 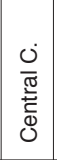 & 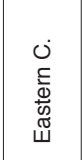 & 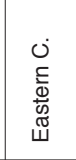 & 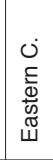 & 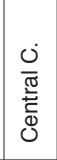 & 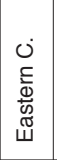 & 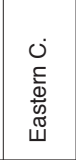 & 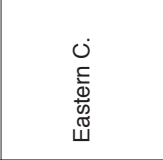 & 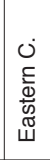 & 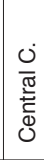 \\
\hline 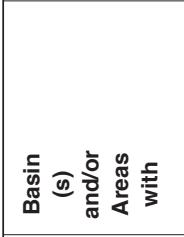 & $\stackrel{\circ}{\stackrel{2}{\alpha}}$ & 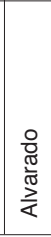 & $\frac{0}{\frac{3}{4}}$ & 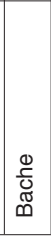 & 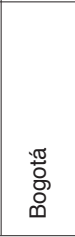 & 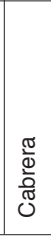 & \begin{tabular}{|l}
$\stackrel{\circ}{\bar{\Phi}}$ \\
Oे
\end{tabular} & 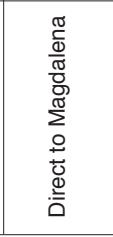 & $\begin{array}{l}\text { 离 } \\
\underline{\underline{z}}\end{array}$ & 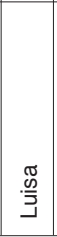 & $\begin{array}{l}\frac{0}{5} \\
\frac{\Phi}{2}\end{array}$ & $\stackrel{\frac{\pi}{2}}{\frac{\pi}{2}}$ & $\begin{array}{l}\frac{0}{\pi} \\
\frac{\pi}{0} \\
0\end{array}$ & 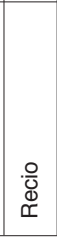 & $\begin{array}{l}8 \\
\mathbb{D} \\
\omega\end{array}$ & 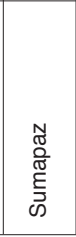 & $\stackrel{\frac{\pi}{0}}{\circ}$ & 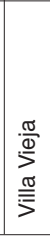 & $\begin{array}{l}\frac{\pi}{\pi} \\
\frac{\pi}{\pi} \\
\frac{\pi}{\pi} \\
\nu\end{array}$ \\
\hline $\begin{array}{l}.0 \\
\frac{0}{9} \\
\frac{0}{0} \\
0\end{array}$ & & & & & & & & & & & 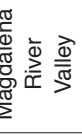 & & & & & & & & \\
\hline$\underline{\dot{\theta}}$ & $\stackrel{m}{\infty}$ & $\ddot{ల}$ & $\hat{m}$ & $\stackrel{\infty}{\infty}$ & ஜ্ల & q & $\bar{\gamma}$ & $\mathcal{F}$ & $\mathcal{F}$ & $\forall$ & 导 & $\mathscr{g}$ & f & $\stackrel{\infty}{q}$ & \& & 요 & in & న్ & \\
\hline
\end{tabular}




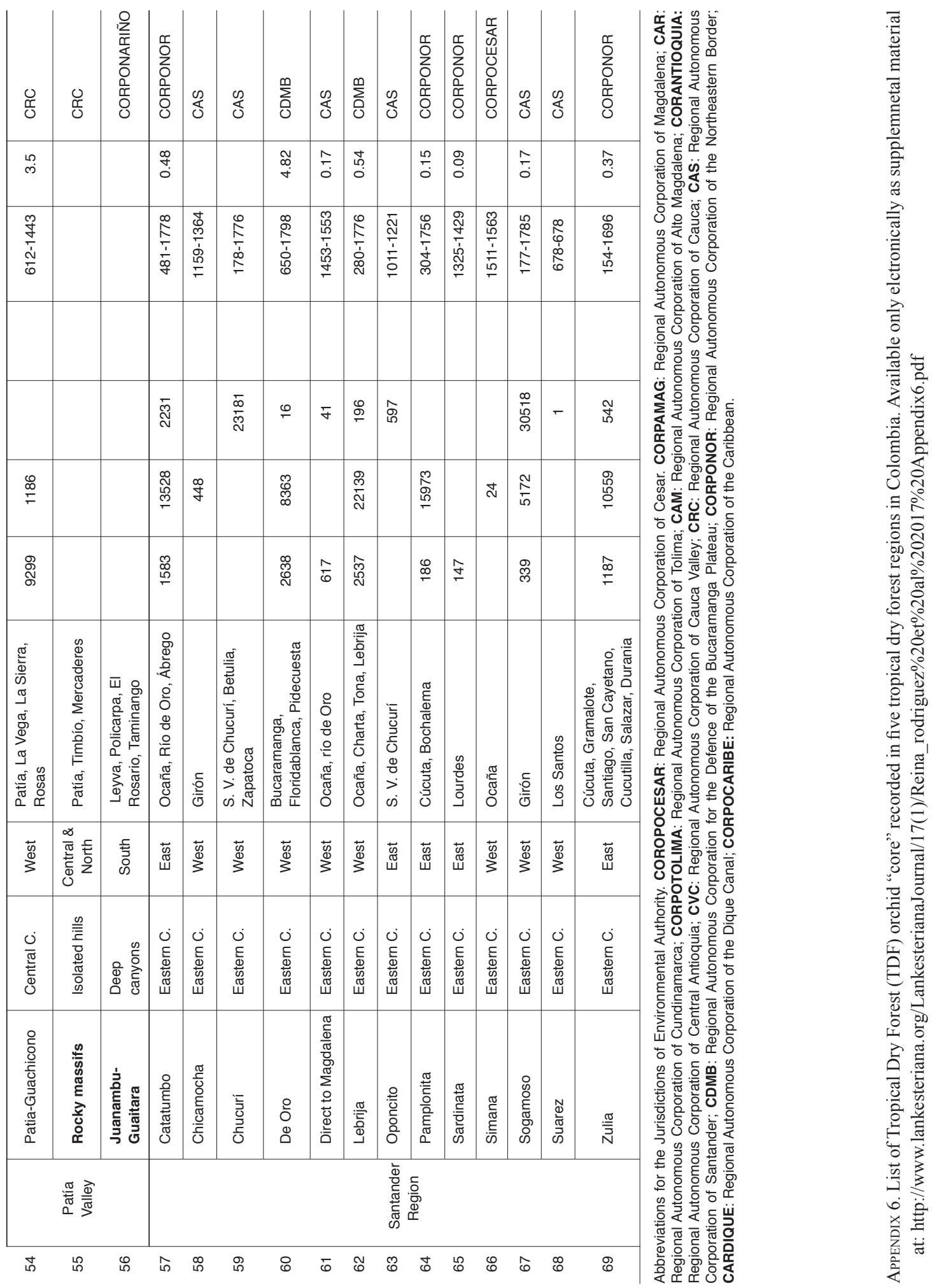


